\title{
POWERS OF APPOINTMENT AND ESTATE TAXES: II*
}

\section{BY LOUIS EISENSTEIN $\dagger$}

IN his statement before the Ways and Means Committee, Mr. Randolph E. Paul, as Tax Adviser to the Secretary of the Treasury, made the following recommendations after briefly summarizing the "serious defects" sanctioning avoidance of the existing statute: ${ }^{1}$

“(1) The estate tax should reach all property subject to a power of appointment, whether exercised or not, other than powers expressly excluded by statute; (2) the powers excluded from the reach of the estate tax should be limited to $(a)$ powers to appoint among the decedent's spouse, his descendants, and spouses of such descendants, (b) fiduciary powers, and (c) powers to appoint for charitable purposes; (3) the executor should be authorized to obtain reimbursement from the appointive property for that portion of the tax which is attributable to such property; (4) the gift tax statute should include the exercise or surrender of all powers subject to the estate tax."

With certain modifications this statement contains a concise resumé of the new statute as finally enacted by Congress. ${ }^{2}$

* The opinions expressed herein represent the personal views of the author, and do not necessarily reflect those of the Treasury Department.

$\dagger$ Senior Attorney, Tax Legislative Counsel's Office, Treasury Department.

1. Hearings before Committee on Ways and Means on H. R. 7378, 77th Cong., $2 \mathrm{~d}$ Sess. (1942) 91. Mr. Paul's summary of existing evils reads: "Since 1918 the estate tax has expressly included in the decedent's estate property which passes under a general power exercised by the decedent. Experience with this provision has disclosed a number of serious defects. The language of the statute provides a generous loophole for the avoidance of tax if the decedent simply refrains from exercising his power. Even if the power is exercised, principles developed by the Supreme Court and the lower courts bar the imposition of an estate tax where the recipients appointed by the decedent are the persons who would take the property in the absence of exercise. Finally, the existing provision reaches only general powers, thereby granting immunity to powers of disposition which are in effect as broad as general powers although technically they do not qualify as such under rules of property law unrelated to taxation." It is clear that $\mathrm{Mr}$. Paul's criticism is addressed solely to the evils of section $811(\mathrm{f})$ of the Code (unless otherwise indicated, sections hereafter cited will be the latest applicable sections of the basic tax system in either the Internal Revenue Code or subsequent amendments), and not to section 811 (a), considered and rejected in Felvering v. Safe Deposit \& Trust Co. of Baltimore, 316 U. S. 56 (1942). See Eisenstein, Pozers of Appointment and Estate Taxes: I (1943) 52 YALE L. J. 296, 338.

2. See also general summaries in H. R. REp. No. 2333, 77th Cong., 2d Sess. (1942) 57 ; Sen. Rep. No. 1631, 77th Cong., 2d Sess. (1942) 55. 


\section{Basic Features of the New Statute}

Section 811 (f) of the Internal Revenue Code, as amended by the $19+2$ $\mathrm{Act}^{3}$ is comparatively simple in structure. although lengthier than the stricken provision. Under the new statute the estate tax base includes:

"any property (A) with respect to which the decedent has at the time of his death a power of appointment, or (B) with respect to which he has at any time exercised or released a power of appointment in contemplation of death, or (C) with respect to which he has at any time exercised or released a power of appointment by a disposition intended to take effect in possession or enjoyment at or after his death, or by a disposition under which he has retained for his life or any period not ascertainable without reference to his death or for any period which does not in fact end before his death (i) the possession or enjoyment of, or the right to the income from, the property, or (ii) the right, either alone or in conjunction with any person, to designate the persons who shall possess or enjoy the property or the income therefrom; except in case of a bona fide sale for an adequate and full consideration in money or money's worth."

The statute defines a power of appointment as "any power to appoint exercisable by the decedent either alone or in conjunction with any purson", with the following two exceptions:

“(A) a power to appoint within a class which does not include any others than the spouse of the decedent, spouse of the creator of the power, descendants of the decedent or his spouse, descendants (other than the decedent) of the creator of the power or his spouse, spouses of such descendants, donees described in section 812 (d), and donees described in section 861 (a) (3)..$^{*}$ As used in this sub-paragraph, the term 'descendant' includes adopted and illegitimate descendants, and the term 'spouse' includes former spouse; and

"(B) a power to appoint within a restricted class if the decedent did not receive any beneficial interest, vested or contingent, in the property from the creator of the power or thereafter acquire any such interest, and if the power is not exercisable to any extent for the benefit of the decedent, his estate, his creditors, or the creditors of his estate."

These provisions correct the defects which have made the former statute "an outstanding device for the avoidance of estate tax" and a generous

3. Pub. L. No. 753, 77th Cong., 2d Sess. (Oct. 21, 1942) $\$ 403$ (hereafter cited as Pub. L. No. 753).

4. Sections 812 (d) and 861 (a) (3) allow a deduction for bequests, legacies, derises, and transfers to specified charitable recipients.

5. See H. R. REP. No. 2333, 77th Cong., 2d Sess. (1942) 160; SE:r. Rep. No. 1631, 77th Cong., 2d Sess. (1942) 232. 
source of confusion. First, a tax modestly confined to general powers is replaced by a levy reaching all powers, whether general, special or hybrid, with the exception of two specifically defined powers. The amendment thus eliminates all the uncertainty and speculation inhering in the phrase "general power," and at the same time broadens the scope of the tax to include nongeneral powers on the basis of tax policy rather than traditional property categories. ${ }^{6}$ There is no longer any need to forage for appropriate definitions among the concepts of the common law. Second, property subject to a taxable power at the date of the donee's death does not escapc tax by a mere refusal by the donee to exercise the power. Legal abstinence is no longer rewarded by tax savings. Now the important factor is the decedent's power to control the destination of the property, not his active intervention in its devolution. Third, the abolition of the requirement of exercise necessarily sweeps away the Grinnell doctrine and the elaborate refinements which have fed upon it and prospered.

One more provision completes the basic structure of the new law. Section 811 (f) (2) of the Code provides that if a power to appoint "is exercised by creating another power to appoint," the first or exercised power does not qualify as one of the excepted powers "to the extent of the value of the property subject to such second power to appoint." This provision is essential to the effective operation of the statute, within its policy considerations, for it is designed to overcome tax avoidance by a succession of tax exempt powers. $A$ may erect a trust bestowing a life estate upon $B$, with a special power in $B$ to appoint among his descendants. Such a power is exempt from tax under the new section. $B$ may do likewise with respect to his son $C$, and estate tax may thus be avoided as long as the succession of special powers linked with life estates is recognized as valid under the local Rule against Perpetuities. In Delaware this process may go on forever because the applicable period of perpetuities is computed anew from each exercise of a special power. ' Section $811(f)(2)$, how-

6. Compare Magill, Federal Regulation of Family Settlements (1937) 4 U. OF CuI. L. REv. 265, 276, suggesting that the distinction between a general power and a special power is perhaps logical in the case of an estate tax, as contrasted with an intheritance tax. See, further, Federal and State Death Taxes in Reports to the Jornt CommitreE on Internal Revenue Taxation (1938) 130. But this seems to be a logic derived from property law rather than a frank appraisal of tax policy.

7. DeE. Rev. CODE (1935) c. 117, §48. See Bettner, The Rule Against Pcrpetuitics as Applied to Powers of Appointment (1940) 27 VA. L. Rev. 149, 164; Leach, Pcrpctilitics in a Nutshell (1938) 51 Harv. L. Rev. 638, 653, n. 37 and Powers of Appointment (1938) 24 A. B. A. J. 807,809 . While Delaware is the only state allowing a continuous procession of special powers, there is always the possibility that others may join in to procure similar tax blessings. Experience at other points of tax incidence has sufficiently revealed that the possibility is far from remote. Cf. California's creation in 1927 of so-called "new" community property, 1 Paul, Federal Estate and Girt Taxation (1942) 59, 212; the adoption of the optional community property system by Oklahoma, C. C. Harmon, 1 T. 
ever, breaks up this convenient parade of tax-free powers by providing for a surrender of immunity if the initial power is exercised by creating another. ${ }^{8}$ As the committee reports emphasize, immunity is lost even if the second power is a taxable power. ${ }^{9}$ Legislative policy is, in short, definitely directed toward forcing property into the open so that the death tax may once more fasten on family wealth. ${ }^{10}$

The House bill merely provided that a power to appoint is not immune from tax as a power of appointment if "exercised to any extent by creating another power to appoint." 11 The difficulty with this provision was that it swept too far afield. $A$, the donee of an otherwise exempt power, might appoint one-half of the property outright to $B$, and subject the other half to a new power held by $C$. Despite the outright appointment the exemption of $A^{\prime}$ 's power would be destroyed with respect to all the appointive assets. The House language was refined in the Senate to provide that the exemption is lost "to the extent of the value of the property" subject to the new power, "unreduced by any precedent or subsequent interest not subject" to the new power. The latter qualification makes certain, for example, that when the donee of the power creates a

C. 40 (1942) ; Daggett, The Oklahoma Community Property Act-A Comparatize Stedy (1940) 2 LA. L. REv. 575, 585, 590; and the more recent adoption of a similar optional system in Oregon, 1 C. C. H. 1943 Fed. Tax Service $\llbracket 0355$.

8. Authority to exercise a power by creating a new power is determincd, of course, by local law. See 3 Restatenrent, Property (1940) \$359; Comment (1937) 50 Hanv. L. Rev. 938. Cf. Miatter of Kennedy, 279 N. Y. 255, is N. E. (2d) 146 (1938). If loal law is silent, the opinion in Helvering v. Stuart, 317 U. S. 154, 163 (1942), indieates that the decision of the circuit court of appeals on the local law issue will not be disturbed by the Supreme Court unless it is brought to "a definite conviction of error." See discussion infra at $548, \mathrm{n} .262$.

9. H. R. Rep. No. 2333, 77th Cong., 2d Sess. (1942) 160; SEx. REP. No. 1631, 77th Cong., 2d Sess. (1942) 232. See also U. S. Treas. Reg. 105, $\$ \$ 1.24$ (b) (2), as added by T. D. 5239, 1943 Int. Rev. Bull. No. 6, at 193; U. S. Treas. Reg. 79, Art. 2(b) (3), as added by T. D. 5241, 1943 Int. Rev. Bull. No. 6, at 227. (All subsequent references to the estate or gift tax regulations dealing with powers of appointment are confined to the additions made by the respective Treasury Decisions).

10. Compare Comment (1943) 43 Cor. L. KEv. 76, S0. It is completely irrelevant for federal tax purposes, whether the appointment is outright or is in trust. In the case of the exemption based on relationship it is suficient that the property, including both life estate and remainder, may not be beneficially appointed to persons without the excepted class. That the statute contemplates appointments in trust is indicatcd by the ban on successive powers, which generally operate via the trust device. But no ban was imposed on appointments in trust as such. Otherwise the exemption would be seriously impaired in the case of minor appointees whose needs are best satisfied by a disposition in trust. Finally, the statutory exception, aside from the proscription of successive powers, does not depend on whether the power is exercised but on the group of possible appointees. If an appointment in trust were authorized-as is commonly the case-and the trustee were considered a separate individual, the power would necessarily be tamable, regardless of exercise, if the trustee were not required to be an exempt relative.

11. H. R. 7378, 77th Cong., 2d Sess. (1942) $\S 403(a)$. 
life estate in conjunction with a new power to appoint the remainder, the entire value of the property is taxable, without any deduction for the life estate, which is not subject to the new power. ${ }^{12}$

\section{Analysis of the Major Changes}

\section{Taxable Transfers}

The new statute taxes property "with respect to which the decedent has at the time of his death a power of appointment." ${ }^{13}$ A power outstanding at the date of the decedent's demise need not be testamentary in order to be taxed. Thus a power exercisable solely by deed and terminated by death falls within the scope of the statute, since the decedent at the moment of death possesses the power to direct the devolution of the property. ${ }^{14}$ The statute also reaches such an obvious avoidance device as a power which must be exercised within a specified period before death. For example, the donor may provide that the power must be exercised within two years prior to the decedent-donee's death. Nevertheless it is the decedent's demise which effects the termination of the power despite any verbalism which shifts the moment of termination to a prior date once death occurs. ${ }^{15}$ Language is also borrowed from section $811(\mathrm{~d})(3)$, re-

12. "Thus, if the decedent has a power to appoint a fund of $\$ 100,000$ within a class consisting only of his children (which is one of the excepted powers) and by his will exercises such power by giving one child a power to appoint $\$ 25,000$ of such fund and by making an outright appointment of $\$ 75,000$, only $\$ 25,000$ is includible in the decedent's gross estate. If, however, the decedent had appointed the income from the entire fund to such child for life with power in such child to appoint the remainder in his will, the whole $\$ 100,000$ would be included in the decedent's gross estate." SEN. Rep. No. 1631, 77th Cong., 2d Sess. (1942) 232. See also U. S. Treas. Reg. 105, \$ 81.24(b) (2). Similarly, if a power is exercised by creating a second power to appoint the income from the property during the life of the second donee, with remainder over to designated persons, the entire value of the property is includible even though the second power is not coterminous with full enjoyment of the property. If the exercise is invalid under local law, tax immunity would presumably not be lost. If a controversy over the alleged invalidity of the exercise were settled by permitting the appointment to remain as to a portion of the property, such portion would probably be taxed. $C j$. Helvering v. Safe Deposit \& Trust Co. of Baltimore, 316 U. S. 56 (1942).

13. Section 811 (f) (1) (A).

14. See U. S. Treas. Reg. 105, $\S 81.24$ (b) (1) ; H. R. Rep. No. 2333, 77th Cong, 2d Sess. (1942) 160; Sen. Rep. No. 1631, 77th Cong., 2d Sess. (1942) 232. Such a power is analogous to a reserved power to revoke a trust or to alter beneficial interests, exercisable only during the settlor's lifetime, either of which renders the trust property taxable at death. Reinecke v. Northern Trust Co., 278 U. S. 339 (1929); Porter v. Commissioner, 288 U. S. 436 (1933). Cf. Chase National Bank v. United States, 278 U. S. 327 (1929). See 1 PaUL, op. cit. supra note 7, \$\$7.08, 7.09.

15. H. R. Rep. No. 2333, 77th Cong., 2d Sess. (1942) 160-61; SEn. Rep. No. 1631, 77th Cong., 2d Sess. (1942) 232: "A power of appointment is deemed to exist at the clate of the decedent's death where the time for the exercise of the power is determined by the date of his death." See also U. S. Treas. Reg. 105, $\$ 81.24$ (b) (1). Cf. Fidelity-Philadelphia Trust Co., 34 B. T. A. 614 (1936). 
lating to reserved powers, ${ }^{16}$ to provide that a power exists on the date of the decedent's death even though its exercise is subject to a precedent giving of notice or takes effect only on the expiration of a stated period after its exercise "whether or not on or before the date of the decedent's death notice has been given or the power has been exercised." ${ }^{17}$ This provision is apparently of a precautionary character, and might well have been omitted except that the failure to include it might give rise to unfortunate inferences in view of the explicit language in section $\$ 11$ (d)(3)..$^{18}$ The latter section has been interpreted in the regulations as reaching reserved powers to revoke, alter, amend or terminate "though the exercise of the power was restricted to a particular time which had not arrived, or the happening of a particular event which had not occurred, at decedent's death." ${ }^{19}$ Although this interpretation may be justifiable in the case of a reserved power in order to forestall avoidance by une who uriginally unjoys full ownership, ${ }^{20}$ wise tax administration should be opposed to a similar position where a power created by another persun is still contingent at the date of the donee's death. If, for example, a puwer is exercisable by the donee after he attains a specified age and he dies at an earliur age, no tax should be imposed because control over the property has failed to materialize. Similar immunity seems warranted where the power fails to ripen as a result of the donee's failure to survive another person. Again, a donee may be authorized to appoint property if he dies without issute surviving, and the property should not be taxable if the decedent is survived by issue. In these cases, the situation is analogous to that of the

16. See H. R. ReP. No. 704, 73d Cong., 2d Sess. (1934) 35 (1939-1 Clas. Bull. Pt. 2, p. 581) ; SeN. Rep. No. 558, 73d Cong., 2d Sess. (1934) 44-45 (1939-1 Cu:s. Burk Pt. 2, p. 620).

17. Section $\$ 11$ (f) (3) ; U. S. Treas. Reg. 105, $\$ \$ 1.24$ (b) (1). Cf. Mellun v. Driccoll, 117 F. (2d) 477 (C. C. A. 3d, 1941), cert. devicd, 313 U. S. 579 (1941); Culunial Trust Co. v. Commissioner, 111 F. (2d) 740 (C. C. A. 2d, 1940); Katherine E. Albrecht, 27 B. T. A. 1091 (1933).

1S. But cf. Mrr. Justice Cardozo's approach in Burnet v. Guggenheim, 288 U. S. 280 , 286 (1933).

19. U. S. Treas. Reg. 105, $\$ \$ 1.20$ (b) (3). Cf. H. R. REp. No. 2\$18, 7tth Cung., 2d Sess. (1936) 10; G. C. M. 11034, XII-2 Cuar. Butr. 271.

20. But see Day v. Commissioner, 92 F. (2d) 179 (C. C. A. 3d, 1437); Tait v. Safe Deposit \& Trust Co. of Baltimore, 74 F. (2d) 851 (C. C. A. fth, 1935); Estate 6i Edward Lothrop Ballard, 47 B. T. A. 784 (1942); Afary Tetzlaff, C. C. H. 1943 T. C. Serv. I 12,941-B (T. Ct. mem.) ; dissenting opinion in Estate of John Howard Helfrich, 1 T. C. 590, 594 (1943). And cf. Commissioner v. Flanders, 111 F. (2d) 117 (C. C. A. 2d, 1940) ; Estate of James W. Henry, 2 C. C. H. 1942 T. C. Serv. T 12,936-G (T. Ct. mem.). See discussion in 1 Paur, op. cit. supra note 7, \$\$7.10, 17.16. Sce also Estate of Mabel Shaw Birkbeck, 47 B. T. A. 803 (1942), which deses nut deserve to survive in view of United States v. Jacobs, 306 U. S. 363 (1939). It scems to las assumed in Robinette v. Helvering, $31 S$ U. S. 184 (1943), that a cuntingent puwer renders trust property taxable under section $\$ 11$ (c) of the Code, by virtue of Helvering v. Hallock, 309 U. S. 106 (1940). Cf. Estate of Peter D. Middlehaufi, 2 T. C. No. 27 (1943). 
contingent remainderman whose death simply obliterates his interest, leaving nothing for the tax collector. ${ }^{21}$

The question raised by powers not exercisable at death may be approached from another direction. Property is taxable at death even though its owner is unable, because of infancy or some other legal incapacity, to transmit it by testamentary disposition. It is therefore arguable that since a donee is treated as outright owner for tax purposes, property stubject to a power should similarly be included in the donee's gross estate even though he cannot exercise the power at death. Thus if a donee died before reaching majority and before acquiring legal capacity to exercise the power ${ }^{22}$ the appointive property would be treated as a taxable asset. This situation might be distinguished from one where the power, for example, is exercisable if the donee survives another person. In the former case the decedent's lack of effective power over the property restilts from a rule of local law; if the donee resided in another jurisdiction he might very well be considered competent to exercise the power. But in the latter case there is no effective power, regardless of local rules, until the necessary contingency occurs. Obviously the line between these cases is exceedingly thin. ${ }^{23}$ A power to appoint property if the donee attains the age of twen-

21. See Commissioner v. Rosser, 64 F. (2d) 631 (C. C. A. 3d, 1933); Hamlin va United States, 66 Ct. Cl. 501 (1928); 1 PavL, op. cit. supra note 7, §4.09. Another analogy is provided by the case of an insured who neither paid the premitums nor enjoyed control over the policy prior to or at death, where his estate was entitled to the proceeds if he survived the beneficiary but the sequence of death was reversed. $C f$. Bailey v. United States, 31 F. Supp. 778 (Ct. Cl. 1940), cert. dismissed on stipulation, 311 U. S. 721 (1940), overruled by Pub. L. No. 753, § 404 (a).

These examples are not to be confused with a power exercisable at death where the enjoyment of the appointive interest must await the termination of a precedent interest. Thus $A$ may have a power to appoint property subject to an outstanding life estate in $B$. If $A$ dies prior to $B$ the value of the remainder is includible in the former's gross estate, after due allowance for $B$ 's life estate. Cf. Camden Safe Deposit \& Trust Co., 30 B. T. A. 287 (1934), where the life tenant had a power to invade corpus in the event the income was not sufficient to maintain her "in the way she is accustomed to live." The Board held that these words created a standard "capable of being stated in definite terms of money." Cf. further Ithaca Trust Co. v. United States, 279 U. S. 151 (1929) ; Estate of Sarah A. Bergan, 1 T. C. 543 (1943).

22. This example is similar to the facts in Helvering v. Safe Depasit \& Trust Co, 316 U. S. 56 (1942). Cf. Estate of Barbey, N. Y. L. J., Oct. 19, 1942, p. 1089, col. 3 (Surr. Ct.). In Great Britain a general power is taxable although the donee is not sti juris at death. See Dymond, Death Dutres (1942) 8. Cf. Sugden, Powers (8th ed. 1861) 177.

23. The line is uncomfortably akin to that drawn, for income tax purposes, between a present right in the settlor to revoke a trust, the revocation being effective at a specified future date unless the settlor dies in the interim, and a power which is contingent upon the occurrence of a specified event. Compare Reuter v. Commissioner, 118 F. (2d) 698 (C. C. A. 5th, 1941) ; Helvering v. Dunning, 118 F. (2d) 341 (C. C. A. 4th, 1941), with Corning v. Commissioner, 104 F. (2d) 329 (C. C. A. 6th, 1939); Commissioner v. Betts, 123 F. (2d) 534 (C. C. A. 7th, 1941). See also the excellent dis- 
ty-one would not be taxable in the event that the donee died at an earlier age; but a power would be taxable if no conditions were imposed by the donor and the donee died while he was unable to exercise the power because of infancy. In both instances the donee is equally unable to affect the devolution of the property. ${ }^{24}$ Yet in other cases the distinction may be quite substantial. For example, an aged donee who has failed to exercise his power for many years when the opportunity readily presented itself, may become mentally incompetent to execute a will shortly before his death. A case along such lines does not seem to deserve the treatment accorded a contingent interest which has never materialized. Perhaps taxability in the case of one unable to exercise his power at death will ultimately depend to a great extent upon whether the donee was ever able to exercise the power.

Section $811(f)(1)(B)$ and $(C)$ imposes tax with respect to powers of appointment exercised or released by a disposition in contemplation of death, or intended to take effect in possession or enjoyment at or after death, or retaining for the decedent control or enjoyment of the property or income during his lifetime. These provisions regarding inter vivos transfers conform generally to the related provisions of the old statute. There are two differences: the new statute, unlike the old, extends to a release, as well as an exercise, by the decedent during his lifetime; ${ }^{25}$ and the new statute refers to a "disposition" intended to take effect at death in lieu of a "deed" to this effect. The term "disposition" secms more advisable from a tax standpoint since "deed" may receive a cramped inter-

senting opinion of Mr. Opper in Henry A. B. Dunning, 41 B. T. A. 1101, 1106 (1940), rev'd, 118 F. (2d) 341 (C. C. A. 4th, 1941); Ray, The Ineome Tax en Short Tcrot asd Rez'ocable Trusts (1940) 53 Harv. L. Rev. 1322, 1334. The Coming decision has bean considered overruled. Altmaier v. Commissioner, $116 \mathrm{~F}$. (2d) 162, 165 (C. C. A. 6th, 1940), cert. denied, 312 U. S. 706 (1940). Cf. First National Bank v. Commicsioner, 110 F. (2d) 448, 450 (C. C. A. 7th, 1940). But cf. Commissioner v. O'Kceffe, 118 F. (2d) 639,642 (C. C. A. 1st, 1941). ". . . the fact that a line has to he drawn somewhere does not justify its being drawn anywhere." Frankfurter, J., dissenting in Pearce v. Commissioner, 315 U. S. 543, 558 (1942).

24. Pub. L. No. 753, $\S 403$ (d) (3) provides that if a donee of a power ereated un or before the date of enactment of the 1942 Act (October 21, 1942) and excrcisable in faver of the donee, his estate, his creditors, or creditors of his estate, is under a legal disability on such date to release the power and dies while under such disability or within 6 months after it ceases, the power is not taxable if it has not been exercised. See U. S. Treas. Reg. $105, \S \$ 1.24$ (b) (3). There is no necessary inference here that the dratters assumal that the power must be exercisable at death in order to entail tax liability. The purpose of the provision is to exempt from estate tax persons unable to relinquish their powers within the grace period afforded by Congress. As a matter of fact. there may be an implication here that a legal disability to exercise a power wuld not prevent the imposition of estate tax since the same disability generally affects both an exercise and a release, [cf. 3 Restatement, Property (1940) \$345], and such disahility would agnarently not bar the levy in the absence of legislative intervention.

25. Compare §\$11(d) (4); U. S. Treas. Reg. 105, \$ \$1.21. 
pretation as a result of its property background. ${ }^{26}$ The operation of these provisions may be illustrated by the following instance: A life tenant of trust property over which he has a power of appointment within the meaning of the statute, relinquishes the power and, in effect, appoints the remainders. At the life tenant's death the trust property is includible in his gross estate. ${ }^{27}$ Another example is afforded by the case of a donee who exercises an otherwise taxable power by creating a trust and reserving a power of revocation. ${ }^{28}$ Moreover, a release during lifetime need not be formal in character. Thus a power may be exercisable for a period of twenty years after its creation, and the donee may permit the power to lapse without expressly surrendering it. In effect the donee has relinquished his power, and its lapse is taxable if it is attributable to contemplation of death or has the required economic effect. ${ }^{20}$ If the decedentdonee has a life estate in addition to the power, the failure to exercise it within the time stipulated renders the property taxable at death because he has retained a life interest. ${ }^{30}$ The same is true if another person has the life estate, where, for example, the donee succeeds to the remainder if the taker gaining by the release predeceases him. ${ }^{31}$

26. Compare Finance Act, 1894, 57 \& 58 Vicr., c. $30, \$ 22(2)$ (a). The word "disposition" would also take care of the unusual case of an "oral" release or exercise, assuming it were possible under local law.

27. U. S. Treas. Reg. 105, $\$ 81.24$ (b) (1).

28. Compare Carrie L. Jones, 41 B. T. A. 1279 (1940), decided under the former statute.

29. "A release of a power of appointment need not be express or formal in character. For example, the failure to exercise a power of appointment within a specified time, resulting in the termination of the power of appointment, is taxable if other conditions imposed by section 811 (f)(1) are present." H. R. REP. No. 2333, 77th Cong., 2d Sess. (1942) 161 ; Sen. Rep. No. 1631, 77th Cong., 2d Sess. (1942) 233. See also U. S. Treas. Reg. $105, \S 81.24($ b) (1). Cf. Allen v. Commissioner, 108 F. (2d) 961 (C. C. A. 3d, 1939), cert. denicd, 309 U. S. 680 (1940); 2 PAUL, op. cit. supra note 7, \$16.04.

30. The incorporation of language taxing a release or exercise of a power where the donee retains a life estate does not involve legislative approval of May v. Heiner, 281 U. S. 238 (1930), and Hassett v. Welch, 303 U. S. 303 (1938). Hence there is no implied attack on the reasoning of Estate of Mary H. Hughes, 44 B. T. A. 1196 (1941), which considers those decisions repudiated by Helvering v. Hallock, 309 U. S. 106 (1940). See 1 PAUL, op. cit. supra note $7, \S 7.15$. The specific language is obviously a practical measure in view of the present state of confusion. The Board, however, has abandoncd its decision in the Hughes case and returned to May v. Heiner. Estate of Edward E. Bradley, 1 T. C. 519 (1943). See also United States v. Brown, 134 F. (2d) 372 (C. C. A. 9th, 1943) ; Brewer v. Hassett, C. C. H. Fed. Inh. Tax Serv. \10,032 (D. Mass. 1943); Fidelity-Philadelphia Trust Co. v. Rothenses, C. C. H. Fed. Inh. Tax Serv. I 10,025 (E. D. Pa. 1943); Blunt v. Kelly, 41 F. Supp. 721 (D. N. J. 1941), aff'd, 131 F. (2d) 632 (C. C. A. 3d, 1942). Cf. Welch v. Terhune, 126 F. (2d) 695,699 (C. C. A. 1st, 1942), cert. denied, 317 U. S. 644 (1942); Commissioner v. Bridgeport City Trust Co., 124 F. (2d) 48, 50 (C. C. A. 2d, 1941), cert. denied, 316 U. S. 672 (1942).

31. Compare Helvering v. Hallock, 309 U. S. 106 (1940); Klein v. United States, 283 U. S. 231 (1931). The regulations, U. S. Treas. Reg. 105, $\$ 81.24$ (b) (1), state that 
A tax occasioned by the release or nonexercise at death of a power of appointment invites a new kind of problem which was nonexistent under the former estate tax statute. Powers of appointment may be renounced or disclaimed, the intended donee refusing to accept any appointive authority. Generally speaking, property cannot be forced upon an unwilling beneficiary, ${ }^{32}$ and the same principle is equally relevant where a power of appointment is bestowed upon another. ${ }^{33}$ Given this legal base, it is not too difficult to visualize the construction of ingenious arguments against taxability. If the donee dies without having exercised the power, the executor may offer the convenient defense that the donee had no power at death since he had previously rejected it. Clearly the effect of a rejection of a power may be the economic equivalent of a release of an accepted power. If $A$ is bequeathed a life estate in conjunction with a power of appointment, and $B$ is the taker in default, a release of the power will indefeasibly vest $B$ 's interest. $B$ is similarly blessed if $A$ rejects the power and it consequently collapses. There is every incentive now to claim that a power was rejected. since one may reasonably assume that the statute does not attempt to tax a rejection of a power if it does not reach a rejection of an outright gift. ${ }^{34}$

if a donee exercises his power by appointing the remainder to his wife if she survives him, otherwise to his estate, the value of the appointed property is includible in his gross estate. This statement assumes that the power is exercisable by deed.

32. See Strom v. Wood, 100 Kan. 556, 164 Pac 1100 (1917); Albany Hospital v. Albany Guardian Society, 214 N. Y. 435, $10 \mathrm{~S}$ N. E. 812 (1915); Bradford v. Leake, 124 Tenn. 312, 137 S. W. 96 (1911) ; Bacon v. Barber, 110 Vt. 280, 6 A. (2d) 9 (1939); see Comment [1938] Wis. L. Rev. 632. Cf. 1 Bogert, Trusts and Trusters (1935) $\$ \$ 150,173$. A renunciation is generally deemed valid as against the creditors of the intended beneficiary. Lehr v. Switzer, 213 Iowa 658, 239 N. W. 564 (1931); Funlse v. Grulke, 204 Iowa 314, 213 N. W. 608 (1927) ; Schoonover v. Osborne, 193 Iowa 474, 187 N. W. 20 (1922) ; Bradford v. Calhoun, 120 Tenn. 53, 109 S. W. 502 (1908). But cf. Estate of Kalt, 16 Cal. (2d) 807, 108 P. (2d) 401 (1940). See discussion in Comment (1938) 47 Yale L. J. 487, 4SS; (1930) 18 Calir. L. Rev. 298; (1939) 37 Mircr. L. REv. 1168.

33. Christian v. Wilson's Ex'rs, 153 Va. 614,151 S. E. 300 (1930), cert. denticd, 282 U. S. 840 (1930). This assumption underlies section 408 of the 1942 Act, amending seetions 812 (d) and 861 (a) (3) of the Code to allow a deduction for an amount falling into a bequest to charity "as a result of an irrevocable disclaimer" of a power "if the disclaimer is made prior to the date prescribed for the filing of the estate tax return." See H. R. Rep. No. 2333, 77th Cong., 2d Sess. (1942) 166; SEN. Rep. No. 1631, 77th Cong., 2d Sess. (1942) 240. Cf. Davison v. Commissioner, 81 F. (2d) 16 (C. C. A. 2d, 1936).

An analogous income tax problem is raised by a renunciation, in contrast to an assignment, of earned compensation. Compare Commissioner v. Giannini, $129 \mathrm{~F}$. (2d) 638 (C. C. A. 9th, 1942), 56 HARv. L. Rev. 313, with Lucas v. Earl, 281 U. S. 111 (1930); Helvering v. Eubank, 311 U. S. 122 (1940). See Helvering v. Stuart, 317 U. S. 154, 168 (1942).

34. A renunciation of a legacy cannot be taxed as a transfer in contemplation of death. Brown v. Routzahn, 63 F. (2d) 914 (C. C. A. 6th, 1933), cerl. devied, 290 U. S. 641 (1933), 33 CoL. L. Rev. 1269. This is an extreme case on its facts. Cf. Estate of 
The imminence of this problem is fully revealed by a statute recently enacted in Massachusetts in response to the federal tax amendments. . $^{\text {jo }}$ It is provided that a donee of a power "may disclaim the same at any time, wholly or in part, in the same manner and to the same extent as he might release it." There seems to be an obvious attempt here to circumvent the federal statute via the route of disclaimer in lieu of release. All one has to do apparently is to use the magic term "clisclaim" and Massachusetts will consider the power as rejected. Federal tax law, however, need not bow abjectly before such local manipulating of property concepts. Since the policy of the federal statute to tax releases is intended to operate on a nationwide basis with fairly uniform effects regardless of local variations, there is implicit in the statute a uniform federal rule for delineating the differences between a release and a disclaimer. ${ }^{36}$ Otherwise, the statute may be conveniently destroyed by state legislation. In determining whether a power was accepted or rejected for tax purposes, the federal courts may summon to their aid the various criteria which are normally employed in common law jurisdictions. ${ }^{37}$ Various factors come into play, such as the time elapsing between the creation of the power and its alleged rejection, and the quality of the acts supposedly indicating a renunciation. ${ }^{38}$ The Gov-

Sarah A. Bergan, 1 T. C. 543 (1943). In the case of a renunciation the property has been treated for succession tax purposes as if the rejected bequest had never been included in the will. People v. Flanagin, 331 I11. 203, 162 N. E. 848 (1928); Natter of Merritt, 155 App. Div. 228, 140 N. Y. Supp. 13 (1st Dep't 1913) ; Matter of Wolfe, 89 App. Div. 349, 85 N. Y. Supp. 949 (2d Dep't 1903), aff'd, 179 N. Y. 599, 72 N. E. 1152 (1904) ; Matter of Clarkson, 137 Misc. 741, 244 N. Y. Supp. 470 (Surr. Ct. 1930) ; cf. Matter of Cook, 187 N. Y. 253, 79 N. E. 991 (1907). The same question of rejection versus release may arise under the gift tax amendment discussed infra at 534 .

35. Mass. Laws 1943, c. 152. See also Ill. Laws 1943, p. 59.

36. Compare United States v. Pelzer, 312 U. S. 399 (1941); Commissioner v. Morgan, 309 U. S. 78 (1940); Burnet v. Harmel, 287 U. S. 103 (1932). Consider further the rule expressly sanctioned in section 408 of the 1942 Act. See note 33, supra. A federal statute, however, reflects its own independent policy, even though Congress has failed to particularize all the facets of such policy. See, e.g., Clearfield Trust Co. v. United States, 318 U. S. 363 (1943); Sola Electric Co. v. Jefferson Electric Co., 317 U. S. 173 (1942) ; D'Oench Duhme \& Co. v. F. D. I. C., 315 U. S. 442 (1942); Deitrick v. Greaney, 309 U. S. 190 (1940) ; Board of Comm'rs v. United States, 308 U. S. 343 (1939).

37. See D'Oench Duhme \& Co. v. F. D. I. C., 315 U. S. 447,472 (1942). Although a federal court may find persuasive materials in local law in fashioning federal policy [cf. Royal Indemnity Co. v. United States, 313 U. S. 289 (1941)], it should certainly refuse "to play, the role of ventriloquist's dummy" [cf. Richardson v. Commissioner, $126 \mathrm{~F}$. (2d) 562,567 (C. C. A. 2d, 1942)] to state legislation designed to facilitate the avoidance of tax by distorting concepts and grossly misusing legal nomenclature. Cf. United States v. Cambridge Loan \& Building Co., 278 U. S. 55, 59 (1928).

38. See discussion in Note (1939) 123 A. L. R. 261. Cf. Camelia I. H. Cerf, 1 T. C. No. 145 (1943). 
ernment may call to its aid the general presumption that a beneficial bequest or gift is presumed to be accepted. There is no reason to confine this principle to powers to appoint to the donee or his estate, for influence and control over wealth and the conduct of others may be as robust where the power is narrower in scope. Even if the power is considered a burden rather than a benefit, it may be deemed a burden inseparably connected with an interest in the appointive property given to the donee, and the one gift must either be accepted or rejected in its entirety. ${ }^{39}$ If the power is created by an inter vivos transfer, with the knowledge of the donee, the claim of renunciation should be entirely foreclosed barring unusual circumstances.

\section{Exempt Powers}

Two powers to appoint property are not considered powers of appointment within the scope of the tax. The first is a power whose appointive class does not include persons other than the spouse of the creator of the power, the descendants (other than the donee-decedent) of the creator or of his spouse, spouses of such descendants, the spouse of the decedentdonee of the power, descendants of the donee or of his spouse, spouses of such descendants. ${ }^{40}$ and beneficiaries within the deduction for charitable bequests. ${ }^{41}$ The other is "a power to appoint within a restricted class" if the decedent-donee did not receive any beneficial interest, rested or contingent, in the appointive property from the creator of the power or thereafter acquire any such interest, "and if the power is not exercisable

39. See Note (1934) 91 A. L. R. 607. Compare the principle that a trustee cannot accept a trust in part and disclaim it in part. 1 RESTATEarent, TRUSTS (1935) $\$ 102(4)$. One may as well recognize that since this question is comparatively novel, the federal courts would be hardly confined in selecting an appropriate rationale for decision. Furthermore, since the context of a case and the objectives of the parties concerned may have a substantial effect on the result reached, the presence of a tas avoidance element may induce the court to hold that requirements of a renunciation hase not been obeyed although another context would have inspired a contrary conclusion. Cf. Coos, The Logical and Legal Bases of the Confrict of Lavs (1942) passim; Hess and Guterman, Annuity Trusts and the Federal Income Tax (1942) 55 Hasv. L. Rev. 329, 335.

40. The statute carefully provides that "descendant" includes "adopted and illegitimate descendants," and that "spouse" includes "former spouse." The Senate report adds: "The treatment of adopted and illegitimate descendants as descendants is intended to include adopted and illegitimate children (and their descendants and their adopted and illegitimate children) as descendants, if such children would be descendants had they been born as natural legitimate children in the station to which they are adopted or born." Sen. Rep. No. 1631, 77th Cong., 2d Sess. (1942) 233. See also U. S. Treas. Reg. $105, \$ \$ 1.24(\mathrm{~b})(2)$. Once an adoption by a donee takes place, the issue of the adopted person are drawn into the class composing the donee's descendants. See, further, Hcarings before Committee on Finance on $H$. R. 737S, 77th Cong., 2d Sess. (1942) 113.

41. Sections $812(d), 861$ (a) (3). 
to any extent for the benefit of the decedent, his estate, his creditors, or the creditors of his estate."

If the first exception made by the statute is viewed in isolation, it seems to be completely at war with the underlying desire to close loopholes. The power of appointment is a mechanism for maintaining control over the donee's intimate family group, for the conduct of others is regulated by the ability to punish or reward. Even if the suspended blessings are reserved exclusively for members of the donee's family, he nevertheless enjoys a nice little bundle of control. ${ }^{42}$ One who owns property outright does not, practically speaking, exert much more control since his power to regulate is similarly exercised through the transmission of property within the family group. Hence the powers which the statute places beyond the reach of the tax seem to be the very powers which should be taxed. Another route leads to the same destination. A donee whose appointive discretion is restricted to the family group enjoys the essential benefits of the broadest general power, namely, the ability to provide for his family and the assurance that the means are at hand. ${ }^{43}$ The persons falling within the appointive class are normally those who would enjoy the fruits of his generosity even if his discretion were unconfined. ${ }^{44} \mathrm{He}$ may, in fact, be considered more fortunate than the donee of a general power since the property is beyond the reach of creditors. ${ }^{45}$

A competing principle, however, apparently comes into play. As the estate tax statute now stands, there is no tax upon the death of the life tenant and the final ripening of the remainder. In short, there is but one tax upon a life estate-remainder sequence, imposed at the death of the person responsible for the sequence. ${ }^{46}$ As long as a life estate and a remainder are subject to one tax levy, the same consequences should flow from a life estate plus a narrow power to adjust the remainder in the light of altered conditions. If all special powers were taxed, testators and grantors would, in all probability, utilize the inflexible life estate-remainder plan of disposition, and forego the benefits of a special power. The small revenue gains would not be worth the loss in flexibility if the power

42. ". . . the donor may also have intended to keep the children under the parents" control where a parent is the donee of the power." Coffin v. Cooper, 2 Drew. \& Sm. 365, 374 (Ch. 1865). Cf. Commissioner v. Buck, 120 F. (2d) 775, 777-78 (C. C. A. 2d, 1941).

43. Compare McDougal, Future Interests Restated: Tradition versus Clarification and Reform (1942) 55 Harv. L. Rev. 1077, 1112 (1942) ; Schuyler, Pozters of Appointment and Especially Special Powers: The Estate Taxpayer's Last Stand (1939) 33 ItL.. L. REv. 771, 780.

44. Compare (1940) 40 CoL. L. Rev. 923, 926.

45. See 3 Restatement, Property (1940) \$326. Cf. Eisenstein, supra note 1, at 316.

46. Compare Mills, Transfers from Life Tenant to Remainderman in Relation to the Federal Estate Tax (1941) 19 TAxEs 195. But $c f$. Dymond, op. cit. supra note 22, at 16, for the English treatment. 
disappeared. ${ }^{47}$ An excepted class of powers should therefore be defined in response to this consideration.

A delicate problem is involved, however, in locating the line separating taxability from immunity. ${ }^{48}$ For instance, the excepted class may be criticized as too broad in view of the guiding policy consideration. The ordinary examples of the life estate-remainder arrangement are a life estate for one's spouse. with a remainder to one's issue, and a life estate to one's children, with a remainder to their issue. The exempt class might therefore be confined, as in the House bill, ${ }^{40}$ to the spouse of the decedentdonee, the descendants of the donee or of his spouse, and the spouses of such descendants. ${ }^{50}$ In the Senate, however, this class was enlarged to include the spouse of the creator of the power, descendants (other than the decedent-donee) of the creator or of his spouse, and spouses of such descendants. ${ }^{.1}$

The class also includes charitable objects in line with the general policy to encourage gifts to charity. ${ }^{52}$ Even without a provision to this effect

47. Compare I Paur, op. cit. supra note 7, at 479; Griswold, Puziers of Aphointmecst and the Federal Estate Tax (1939) 52 Hanv. L. Rev. 929. 958; Leach, Powers of Aprointment and the Federal Estate Tax-A Dissent (1939) 52 H.asv. L. Rev. 901, 965, n. 2; Lowndes, Tax Avoidance and the Federal Estale Tar (1940) 7 LAw \& Co:TEMr. Pros. 309, 322; Paul, The Emergency Job of Federal Taration (1941) 27 Cos:. L. Q. 3, 12.

48. The line may be drawn by taxing all powers, subject to a carefully defined exception, or by defining affirmatively the powers which are subject to tax. The former method, reflected by the statute, is clearly superior, since it is practically impossible to achieve a satisfactory affirmative definition of all powers which should incur tas. But $d f$. Leach, supra note 47 , at 966 . The definition would have to foresce all kinds of ingenicus contrivances, and powers functioning for purposes of avoidance might easily eccape the statutory net. It is comparatively simple to except those special powers which merit immunity.

49. H. R. 7378, 77th Cong., 2d Sess. (1942) $\$ 403(a)$. See also Statement of Randolph E. Paul, quoted supra at 494.

50. A statute which includes the donee's descendants in the excepted class of objects may as well include their spouses in order to allow for the necessary flexibility. Cf. Griswold, supra note 47, at 960, suggesting a tax on special powers, but excepting "any power which could be exercised only among the children of the donor or of the donee, and when the property, in default of appointment, is to be distributed among the elass." See also 1 PAUL, op. cit. sitpra note 7, at 480 .

51. Sen. Rep. No. 1631, 77th Cong., 2d Sess. (1942) 233; CoNr. Rep. No. 2586, 77th Cong., 2d Sess. (1942) 69. The Senate report states: "The limitation exeluding the decedent from the excepted group of descendants of the creator of the power or his spouse, is not intended to exclude from the excepted group the srouse of the decedent, who is expressly included in the group. The description of these persons as an excepted class is intended to be construed so as to give uniform Federal applieation." See also U. S. Treas. Reg. 105, $\$ 81.24$ (b) (2). The language of the regulation is broad enough to deny the exemption if one of the favored relatives is also a creditor. It is extremely doubtiul, however, whether this interpretation was intended by the Treasury. Cf. Comment (1943) 43 CoL. L. REv. 76, 78, n. 13.

52. See X. M. C. A. v. Davis, 264 U. S. 47,50 (1924). The time seems to be ripe for a re-examination of this deduction. Compare the Treasury's propusal to limit the 
the decedent's estate would be entitled to a deduction for an appointment to charity under section 812 (d) or section 861 (a) (3) of the Code, as amended by the 1942 Act. $^{53}$ The purpose of the provision is to assure immunity where the assets are not appointed to charity, and therefore are not taken out of the taxable estate as deductions. ${ }^{54} \mathrm{~A}$ person interested in creating a tax-free power which embraces charitable recipients should make certain that they satisfy the requirements of section $812(d)$ or 861 (a) (3). If there is a defect on this score the immunity of the power disappears. ${ }^{55}$

It is important to note that taxability because of a power outstanding at death depends upon the relationship of the appointive class at that moment. Assume that the donee receives from his brother, who is childless, a power to appoint property to the donee's children, who are also the takers in default, or, if there are no children, to the children of another brother. If the donee, at the date of death, has no children, the existence of the other class of eligible appointees will render the power taxable, since the persons within the latter class do not fall within the statutory exception. The creator of the power may accomplish practically the same result without concomitant tax liability by providing that the persons composing the substituted class should take in specified shares in the event that the donee has no children. At his death the donee has no power of appointment. $^{56}$

The question may arise whether the takers in default should not be considered in determining whether the appointive class is sufficiently limited for purposes of tax immunity. Certainly in a broad sense the takers in default are within the donee's area of discretion, for by refraining from

charitable deduction, as summarized in Statement of Mr. Paul, supra note 1, at 21 . Sec, further, Griswold, Cases and Materials on Federal Taxation (1040) 264; 1 Pavi, op. cit. supra note 7, § 12.28; Harriss, Philanthropy and Federal Ta.t Excmption (1939) 47 J. PoL. Econ. 526.

53. Pub. L. No. 753, $\S 403(\mathrm{~b})(1)$ and (2). Under the prior law it was not clear whether an appointment to charity qualified as a deduction. See 1 PAUL, op. cit. supra note 7, at 421; Griswold, supra note 47, at 950. The committee reports on section 403(b) (1) and (2) of the 1942 Act state that it is "clarifying with respect to property passing to charity under a general power of appointment exercised by the dececient and includible in his gross estate." H. R. Rep. No. 2333, 77th Cong., 2d Sess. (1942) 161; SEN. REP. No. 1631, 77th Cong., 2d Sess. (1942) 233.

54. See discussion at p. 525 infra.

55. The power may still be exempt if appropriately confined to a restricted class. See p. 509 infra.

56. It may be possible, depending largely upon the language creating the power, to avoid estate tax by means of an adoption. Suppose $A$ has a testamentary power to appoint to his issue and, if no issue survive him, a general power of appointment. If the donce has no natural issue, he may adopt his appointee and thereby retain his exempt special power. Local law will determine whether a power to appoint among issue includes adopted children. 
exercise or by releasing the power the appointive property may be directed to persons without the exempt class. But the statute apparently confines its interest to those persons whom the donee may affirmatively designate as the recipients of the property, as distinguished from those who benefit by the donee's inactivity. $=$ It seems fairly safe to assume therefore that the exempt character of the appointive class is not affected by the relationship of any of the takers in default, ${ }^{\text {,18 }}$ especially since a power is generally regarded as an authority to determine the relative interests in property, ${ }^{59}$ whereas the respective shares in the unappointed property are settled by the creator of the power, and cannot be reallocated by the donee. ${ }^{60}$

The second statutory exception, according immunity to "a power possessed by a disinterested trustee or one occupying a sinilar status to appoint within a relatively small class," ${ }^{01}$ is the so-called "fiduciary power" referred to in Mr. Paul's statement before the Ways and Means Committee. ${ }^{62}$ A power falling within this exception should, in most cases,

57. This conclusion does not contradict the earlier assertion that ceonomically the nonexercise of a power is one way of exercising it. See Eisenstein, supra note 1, at 303. As already indicated, the statute seems to except certain powers because of the favorcd status accorded the life estate-remainder sequence. Since the possible appointees might have been designated as the recipients of the property without any power hanging over their interests as a sword of Damacles, other takers in default become relatively unimportant, as the designation of remoter kin is a reasonable contingent disposition in the event that closer kin are not present to receive the property. But compare Professor Griswold's suggestion, supra note 50 .

58. Compare 3 Restatearent, Property (1940) $\$ 318$. Discretion is not absolute in the case of a non-exclusire power. Id. $\$ \$ 360,361$.

59. A donee might be required to appoint to certain persons in specifically stated proportions or permit the property to pass by default in other stated proportions to another group of persons which is not identical with the former class. But this type of power is a rara azis and does not satisfy the needs of flexibility to which a power of appointment traditionally responds.

60. Again, one may note the possibility of unusual arrangements for the devolution of property. The donee might have a power to appoint within the excepted group of relatives specified by section 811 (f) (2) (A), his estate being the talser in default. Actually, however, the donee in this case has a taxable power since he may allocate the various portions among persons without the class specified in the above section. But of. Comment (1943) 56 HARv. L. REv. 428, 454. The donee's estate might become entitled to a share in default of appointment because of the death of a person originally designated by the donor as a taker in default. Cf. Dyssown, op. cit. supra note 22, at 8 .

61. H. R. Kep. No. 2333, 77th Cong., 2d Sess. (1942) 161; SEN. KE.P. No. 1631, 77th Cong., 2d Sess. (1942) 233.

62. See Sev. Rep. No. 1631, 77th Cong., 2d Sess. (1942) 55. Cf. Finance Act, 1894, 57 \& 58 VICr., c. 30, $\$ 22(2)$ (a), exempting "fiduciary powers" from death tax impased with respect to general powers. See GReEn, Deitr DurIEs (1936) 48. Instead of employing the term "fiduciary" and leaving the details to the courts, section 811 (f) (2)(B) contains a detailed description of the power which it is desired to exempt. This technique avoids the ambiguities lurking in "ffiduciary." See Palmer v. Locke, $15 \mathrm{Ch}$. 294, 302 (1879). Cf. Griswold, A Plan for the Coordination of the Incone, Estale, ond Gifi 
enjoy immunity by virtue of the first exception based on relationship. The purpose of the second exception is to extend immunity to cases where the power is essentially a burden and similarly confined to a comparatively small group. ${ }^{63}$ Here again there is a concession to the needs of flexibility. The committee reports carefully indicate the meaning of "restricted class": "For example, a power to appoint within a class composed of A's children would be a power to appoint within a restricted class. On the other. hand, a power to appoint to anyone except $\mathrm{A}$ and his family would not be a power confined to a restricted class." "is The term "class" has no technical property connotation, as, for example, a group of takers intended to fluctuate in number. ${ }^{65}$ It is simply a question of the number of persons eligible as appointees at the taxable moment. ${ }^{60}$ Of course, one may, without undue strain, imagine cases where it would be difficult to determine whether the appointive group qualifies as a restricted class, ${ }^{17}$ but a person who really desires to create a "fiduciary power" is sufficiently protected by the statutory language.

There is another requirement, aside from the restricted character of the class, to be satisfied. The donee must "not receive any beneficial interest, vested or contingent, in the property from the creator of the power or thereafter acquire any such interest," and the power must not be "exer-

Tax Provisions with Respect to Trusts and Other Transfers (1942) 56 HARv. L. Rev. $337,345-46$.

63. Compare 1 PAUL, op. cit. supra note 7, at 413: "A power of appointment may be more in the nature of a trust or even a power of attorney, leaving the donee with no beneficial rights of his own and merely burdening him with responsibility and oncrous duties, as in a case in which the donor devises property for the benefit of his children, vesting in a trusted friend the power to distribute the property among the children by his last will in the manner he deems most in keeping with the prestumable intent of the donor."

64. See Sen. Rep. No. 1631, 77th Cong., 2d Sess. (1942) 233; H. R. Rep. No. 2333, 77th Cong., 2d Sess. (1942) 161 (with a slight variation in language). The Senate report adds: "Moreover, a power to appoint is not confined to a restricted class because the power is not exercisable in favor of the decedent, his estate, his creditors, or the creditors of his estate, or all of them."

65. See 3 Restatement, Property (1940) §279; Cooley, What Constitutes a Gift to a Class (1936) 49 HARv. L. REv. 903.

66. When the power is created the number of possible appointees may exceed the bounds of "restricted." At the donee's death, however, the number of eligibles may be so reduced through death or other causes as to render the power exempt.

67. Compare 3 Restatenient, Property (1940) $\$ 320$, stating that in order to qualify as special, a power must be exercisable "only in favor of persons, not including the donee, who constitute a group not unreasonably large." This statement is amplified by comment $d$, which declares that a power to appoint to the relatives of $A$ is not a power to appoint to a group unreasonably large even if "relatives" includes all blood relatives. "This, however, is about the limit of permissible breadth. Powers to appoint to the friends or acquaintances of the donor, or to any person except the donee or his spouse, or to any resident of Massachusetts are examples of group descriptions too broad to create a special power as here defined." 
cisable to any extent for the benefit of the decedent. his estate, his creditors, or the creditors of his estate." This condition is in line with the purpose of the exemption, and aids in delineating the nature of the power qualifying for immunity. The exemption is lost if at any time after the creation of the power the donee acquires any beneficial interest in the property, even if not directly from the creator of the power. And it makes no difference if the beneficial interest is contingent or remote. ${ }^{\text {cs }}$ Indeed it would be difficult to trace a line of demarcation in terms of "vested" or "contingent", since a contingent renainder may be extremely valuable; nor would it be simpler to make distinctions in the light of remoteness and propinquity, for there is no workable yardstick which would lend itself easily to a proper interpretation of "legislative" intention. ${ }^{69}$ However, despite the breadth of the provision, a few qualifications seem to be required if a fair and reasonable administration is to be achieved. Thus a trustee's commission payable out of the appointive property ${ }^{70}$ should not per se have any adverse effect; otherwise the exemption would be deprived of any practical value. But if the donor provides for a commission, payable out of the property, which is in excess of the customary allowance under local law, it might be held that the proscribed beneficial interest exists. Again, the mere fact that the donee has some beneficial interest in the property should not destroy the exemption, if the interest is commensurate with the donee's services and requires the performance of such services. ${ }^{71}$ The donee may still be considered "disinterested" whether or not he is a trustee. Finally, the statute does not withdraw immunity merely because the donee receives other property, not included in the appointive assets, from the creator of the power. ${ }^{72}$

68. Compare Fidelity-Philadelphia Trust Co. v. Rothensies, C. C. H. Fed. Inh. Tax Serv. 丹 10,025 (E. D. Pa. 1943) ; Estate of Horatio Gates Lloyd, 47 B. T. A. 349 (1942) ; John E. Cain, Sr, 43 B. T. A. 1133 (1941). But ef. Commissioner v. Kellogg, 119 F. (2d) 54 (C. C. A. 3d, 1941); Estate of Charles Delany, 1 T. C. $7 \$ 1$ (1943). Once the donee acquires the forbidden property interest, the damage is apparently done. The statute withdraws the benefit of the exemption even if the interest is released. The remedy of a donee who desires to stay within the exemption is to reject the property interest.

69. Compare 1 PAUL, op. cit. sipra note 7, at $\$ 7.28$.

70. Compare Commissioner v. Davis, 132 F. (2d) 644 (C. C. A. 1st, 1943).

71. Compare United States v. Merriam, 263 U. S. 179 (1923); Bank of New York v. Helvering, 132 F. (2d) 773 (C. C. A. 2d, 1943), with Ream v. Eowers, 22 F. (2d) 465 (C. C. A. 2d, 1927) ; Rose v. Grant, 39 F. (2d) 338 (C. C. A. 5th, 1930), disinissed on motion of petitioner, 283 U. S. 867 (1931). See 1 MERTE*rs, LAW gF FeuzRn Iscouse Taxation (1942) $\$ 6.04$. The policy seems to be to divorce the holder of the property from any beneficial interest as such in the property.

72. It has been suggested that in order to lose the exemption the donee must not have any interest in the rights subject to the power and not simply in the res. Thus a power of appointment over the remainder, held by a life tenant, could qualify as a "fidu- 
The "fiduciary power" excepted by the statute calls for a thorough overhauling of trust mores. It is not unusual for a settlor to bestow powers of revocation and amendment upon one or more trustees, ${ }^{73}$ in whom he has complete confidence on the basis of such factors as relationship, ${ }^{74}$ business association, or intimate friendship. This authority vested in the trustees is, in legal effect, a power of appointment not confined to a restricted class or to the exempt class of relatives, ${ }^{75}$ even though

ciary" power. See Comment (1943) 43 CoL. L. REv. 76, 78. But this construction, which is obviously not borne out by the statutory language, would obviously undermine the first exception, carefully based on relationship, by extending the exemption to practically all special powers. Only in comparatively rare cases does the donee of a special power have an interest in the rights which may be appointed.

73. The estate tax consequences at the settlor's demise are not clear at the present time. Compare Blunt v. Kelly, 131 F. (2d) 632 (C. C. A. 3d, 1942); Brewer v. Hassett, C. C. H. Fed. Inh. Tax Serv. I 10,023 (D. Mass. 1943) ; Chase National Bank v. Higgins, 38 F. Supp. 858 (S. D. N. Y. 1941), with Helvering v. St. Louis Union Trust Co., 296 U. S. 39 (1935), overruled in another connection by Helvering v. Hallock, 309 U. S. 106 (1940) ; Billings v. United States, 24 Am. Fed. Tax Rep. 1161 (S. D. Cal. 1939); Anna B. Kneeland, 34 B. T. A. 816 (1936). See Higgins v. Commissioner, 129 F. (2d) 237, 239 (C. C. A. 1st, 1942), cert. denied, 317 U. S. 658 (1942); Herzog v. Commissioner, 116 F. (2d) 591,595 (C. C. A. 2d, 1941). In so far as the gift tax is concerned, it seems clear enough that a trust reserving appointive control in the trustees is subject to gift tax. Higgins v. Commissioner, 129 F. (2d) 237 (C. C. A. 1st, 1942), cert. denied, 317 U. S. 658 (1942); Albert D. Lasker, 1 T. C. 208 (1942); cf. Herzog v. Commissioner, 116 F. (2d) 591 (C. C. A. 2d, 1941); Rheinstrom v. Commissioner, 105 F. (2d) 642 (C. C. A. Sth, 1939); Estate of Ben F. Hazelton, Jr,, C. C. H. 1940 B. T. A. Serv. $\llbracket 11,297-F$ (B.T.A. mem.). But $c f$ the contrary assumption in Cockrell v. United States, $39 \mathrm{~F}$. Supp. 148 (Ct. Cl. 1941). These questions are considered in detail in 1 PAUL, op. cit. supra note $7, \$ \$ 7.12,17.11$.

74. Compare, for example, the powers of the husband-trustee in Lillian M. Newman, 1 T. C. 921 (1943), and of the wife-trustee in Estate of Edward Lothrop Ballard, 47 B. T. A. 784 (1942).

75. Here, again, federal taxation makes uncomfortable contact with local property law. The language of a trust instrument may be very deceiving, for local law may read ostensibly broad powers of disposition in grudging fashion. For example, in Helvering v. Stuart, 317 U. S. 154 (1942), the trustees, other than the settlor, were empowered "to alter, change or amend this Indenture at any time and from time to time by changing the beneficiary hereunder . . . or in any other respect." The circuit court of appeals determined, on the basis of local law, that this language did not authorize the trustees to convey the property to the settlor. A majority of the Supreme Court acquiesced in this conclusion although, as the dissenting Justices contended, there was no local decision holding or suggesting that the circuit court was right. The Stuart decision seems to impose a serious limitation upon the presumption in favor of the Commissioner's determination. Cf. Leser v. Burnet, 46 F. (2d) 756 (C. C. A. 4th, 1931).

The regulations state that "ordinarily, powers of management with respect to property in trust, such as the determination of whether distributions shall be annually or quarterly, the making of investments and reinvestments, or the determinations of itcms of income and principal under recognized rules of accounting, are not powers of appointments over property under section 811 (f)." U. S. Treas. Reg. 105, $\$ \$ 1.24(b)(1)$. On the other hand, one may have a power of appointment over income. Cf. Camelia I. H. 
intended to be exercised in accordance with the settlor's desires. ${ }^{70}$ Furthermore, even if the appointive group is "restricted," the power may still be taxable because the trustee has received some interest in the trust property, perhaps of an extremely remote character. All such powers must be surrendered prior to March 1,1944, or remain unexercised, depending upon the scope of the power; otherwise they will be swept into the orbit of the amendments. ${ }^{i \pi}$ Despite this inroad upon trust practice, the statute represents a reasonable effort to sustain its policy considerations and, at the same time, permit the continuance of a healthy flexibility in trust administration. $^{78}$ Settlors who desire to avail themselves of the services of others may do so by narrowing the scope of appointive discretion within the limits delineated by the statute, and complying with other requirements of immunity. More attention must be devoted to tax cunsequences, but increased vigilance is a small price to pay for tax immunity..$^{70}$

Since the "fiduciary power" is not dependent upon the relationship of the appointive class, it seems clear enough that immunity is not lost if charities are included in the class. One may proceed one step further, as the regulations ${ }^{80}$ do: There is no limit upon the number of charities which may be included in the class as long as they all satisfy the requirements of section 812(d) or 861(a)(3). All such charities should be regarded as one object in view of the desire to encourage gifts for chari-

Cerf, 1 T. C. No. 145 (1943). Thus $A$ may create a trust for the life of $B$, authorizing $C$ to appoint the income to any persons other than $C$, his estate, or creditors. At $C$ s death the income subject to his power of disposition should be included in his gross estate Cf. Commissioner v. Bridgeport City Trust Co., 124 F. (2d) 4S (C. C. A. 2d, 1941), cert, denied, 316 U. S. 672 (1942); Estate of Edward Luthrop Ballard, 47 B. T.A. 784 (1942).

76. See also p. 516 infra, discussing powers exercisable jointly by the grantor and the trustee.

77. See p. 542 infra.

78. Mr. Colin F. Stam, Chief of Staff of the Joint Committee on Internal Revenue Taxation, has observed: "It is believed that the present law may result in hardship upon the fiduciary with a general power and require the property subject to the power to be included in the trustee's own estate; although he had no personal interest in the property and was never intended to have any such personal interest." Sex. Rep. No. 1832, 77th Cong., 2d Sess. (1942) 1. This criticism hardly does justice to the statute, which carefully protects trustees. A person holding a general power does nut deserve immunity regardless of his simultaneous enjoyment of the title of trustee. On the other hand, if he desires to function as a "fiduciary" the statute permits him to do so without any tax burden. The only hardship here seems to be a tax which there is no need to incur.

79. We have reached a point where tax incidence has become a crucial factor in the development of property law. Perhaps it might be more correct to say that many recent phases in the development of property law derive basically frum a tax law which continues to cut more deeply and widely. Mlany trust instruments, for esample, would never be written if tax consequences did not intrude. The law of powers of appointment is also stimulated by the search for freedom from tax.

80. U. S. Treas. Reg. 105, §\$1.24(b) (2). 
table purposes. But this policy consideration is not applicable if the recipients do not meet the conditions of the estate tax statute. In that case each should be regarded as a separate object in determining whether the class is restricted. A careful appraisal of the charities placed in the appointive group is therefore in order. However, even if the power is taxable, the property may escape tax by the deduction route if the appointee or taker in default qualifies under either of the above sections. ${ }^{81}$

\section{Powers Exercisable in Conjunction with Another Person}

Section $811(\mathrm{f})$, as amended by the 1942 Act, provides that a power is taxable whether exercisable by the decedent "alone or in conjunction with any person." 82 An analogous provision in section 811 (d), dealing with reserved powers, has been sustained by the Supreme Court in Helvering ${ }^{\prime}$. City Bank Farmers Trust Company. ${ }^{83}$ The Court observed that section 811 (d) was intended to prevent avoidance of the estate tax "by the device of joining with the grantor in the exercise of the power of revocation someone who he believed would comply with his wishes. Congress may well have thought that a beneficiary who was of the grantor's immediate family might be amenable to persuasion or be induced to consent to at revocation in consideration of other expected benefits from the grantor's estate." Therefore, Congress could constitutionally provide that if a grantor of a trust "saw fit to reserve to himself jointly with any other person the power of revocation or alteration, the transaction should be deemed to be testamentary in character; that is, treated for the purposes of the law as intended to take effect in possession or enjoyment at the death of the settlor." 84

The situation is not exactly the same, however, where a power exer" cisable with the consent of another person has been bestowed upon the decedent. Whereas a settlor, as master of the trust property, may join with him one who is "amenable to persuasion," a similar opportunity is not accorded the donee of a power. The choice is in the donor, who may actually attempt to fetter the donee's discretion, rather than circumscribe narrowly the class of potential appointees. In view of the difference in context between a power falling within section $811(\mathrm{~d})$ and a power of appointment, it may be argued that an exception should be made for those

81. See p. 525 infra.

82. Section $811(f)(2)$ of the Code.

83. 296 U. S. 85 (1935). Section $811(\mathrm{~g})$ of the Code, as amended by Pub. L. No. $753, \S 404$, now contains a similar provision to the effect that insurance upon the life of the decedent, payable to specific beneficiaries, is taxable where the decedent has at the date of death "any of the incidents of ownership, exercisable either alone or in conjunction with any other person." This provision overcomes a number of decisions to the contrary. See 1 PAul, op. cit. supra note $7, \$ 10.22$.

84. 296 U. S. at 90, 92. Cf. Flood v. United States, 133 F. (2d) 173, 177 (C. C. A. 1st, 1943) ; Commissioner v. Prouty, 115 F. (2d) 331, 335 (C. C. A. 1st, 1940). 
cases where the person whose consent is required maintains a real control orer the appointment. ${ }^{8 . "}$ Experience, however, with the "substantial atverse interest" concept in the income tax statute ${ }^{83}$ indicates that a factual study of control in each case is impractical, engenders uncertainty and invites litigation. ${ }^{\mathrm{si}}$ The best solution. in riew of the avoidance possibilities lurking in a formal veto power given to another, is a blanket pruvision including all powers otherwise taxable whose exercise is dependent upon the consent of others. This provision, incorporated in the new statute. is reasonable for purposes of due process, ${ }^{83}$ and any individual hardships are outweighed by the closing of a loophole to avoidance. In addition. this protective device does not in itself seriously hamper the use of powers to achieve flexibility in family settlements. ${ }^{89}$

A tax upon powers exercisable in conjunction with another person does, however, present a problem which requires careful administration. If two persons must agree upon the exercise of a power, how is the dunce to be distinguished from the person whose consent is required for the exercise? ${ }^{90}$ Or does the statute reflect a desire to consider either one as the donee of the power and therefore subject to estate tax? In the case of a joint power ${ }^{91}$ the persons concerned are commonly regarded as equal participants in directing the devolution of the property, to be

85. Compare 1 PaUr, op. cit. supra note $7, \$ 9.11$.

S5. Sections $166,167$.

87. See Paul. Studies in Federal Taxition, Tuird Series (1940) 213; 2 Pavl, op. cit. supra note $7, \S 17.10$; Ray, supra note 23 , at 1324 .

SS. Compare Morgan v. Commissioner, 309 U. S. $7 S$ (1940). In Rodicek v. Helvering, 87 F. (2d) 328 (C. C. A. 2d, 1937), it was held that the decedent's will cuuld be regarded as a "generating source" of the transfer even though its provisions might be revised by others after his death.

\$9. Generally, it seems, one of the major purposes of a provision requiring the consent of others is to keep the property within the family. Cf. Charles J. Hepburn, 37 B. T. A. 459 (1938).

90. This problem does not arise under section $811(\mathrm{~d})$, tasing inter vivus tranclers where a power to revoke or alter, exercisable in conjunction with another, is reserved to the transferor. The tax is imposed only upon the estate of the persin who owned the transferred property. Brown v. Commissioner, 119 F. (2d) 983 (C. C. A. 7th, 1941); Colonial Trust Co. v. Commissioner, 111 F. (2d) 740 (C. C. A. 2d, 1940); see Commissioner v. Solomon, 124 F. (2d) 86, 89 (C. C. A. 3d, 1941); if. Lehman v. Cummissioner, 109 F. (2d) 99 (C. C. A. 2d, 1940), cort. denicd, 310 U. S. 637 (1940); Estate of Frederick S. Fish, 45 B. T. A. 120 (1941). Compare section 811(e), providing that property held jointly or by the entirety is tasable to the extent of the decedent's contribution, and that if property so held is acquired by inheritance or bequest, one-hali is attributable to the tenant dying first. Pub. L. No. 753, $\$ 402$, changing the estate tax status of community property, similarly taxes to the decedent the progurty attriliutable to his or her economic efforts or separate property. However, in nu event is the value of the included property less than the value of the property subjeut to the decedent's puwer of testamentary disposition. See H. R. Rep. No. 2333, 77th Cong., 2d Sess. (104?) 169; Sex. Rep. No. 1631, 77th Cong., 2d Sess. (1942) 231.

91. Compare Ryerson v. Commissioner, 312 L'. S. 405 (1941). 
distinguished from the situation where one person is entrusted with the necessary discretion, subject to the other's restraint. ${ }^{92}$ Ustally, it seems, the donee of a power is the person upon whose death the exercise or gift in default takes effect. Thus if $A$ has a life estate preceding the appointivc remainder, and the concurrence of $B$ is required in order to exercise the power, the estate tax should not ordinarily attach at $B$ 's death even if the power thereupon disappears. But the power may reside in persons who do not enjoy any interest in the appointive assets, as, for example, three trustees. If the power survives the death of each until the death of all three, is there a tax upon the estate of each trustee ${ }^{.03}$ or is the tax suspended until the death of the last surviving trustee, or is taxability determined by some factor other than the sequence of death or the effect of death upon the power? Also, the problem may become acute when the persons involved have substantial stakes in the property. For example, income from property may be bequeathed to $A$ and $B$ for their joint lives, with all the income payable to the survivor, in conjunction with a power in $A$ and $B$ to be exercised jointly, or a power in the survivor if the power remains unexercised.

The regulations ${ }^{04}$ apparently approach the problem by way of the specific factual pattern. Generalities are carefully rationed, thus indicating a case-by-case process of inclusion and exclusion. It is provided that if $A$ transfers property in trust for the life of his son $B$, authorizing him to alter, amend, revoke, or terminate the trust with the consent of the trustee, the entire property is includible in B's estate at his death. Furthermore, if "the trustee is a disinterested third party not receiving any beneficial interest upon such transfer," the trust property is not includible in the trustee's estate in the event that he predeceases $B$. "Similarly, if property is transferred in trust by a grantor reserving the power to alter, amend, revoke or terminate the trust with the consent of the trustee who is a disinterested party not receiving any beneficial interest upon the transfer, the value of the property is not includible in such trustee's personal estate if he should predecease the grantor." In short, the regulations seem to take the position that a person is not taxed merely because his concurrence is a prerequisite of a valid exercise of a power.

In the case of the life tenant who has a power exercisable with the consent of the trustee, the latter's immunity is carefully hedged with the assumption that he is "disinterested" and does not receive "any beneficial interest" upon the transfer. There seem to be at least two implications

92. The Restatement makes a distinction but offers no assistance. It states briefly, "A power may be created in two or more persons to be exercised by them jointly. A power may be exercisable by the donee only with the assent of some other person." 3 Restatement, Property (1940) $\$ 318$, comment $f$.

93. It is assumed that the trustee, if a donee, is not entitled to immunity.

94. U. S. Treas. Reg. 105, $\$ 81.24$ (b) (1). 
here. First, a trustee who has a beneficial interest in the property may be treated as a donee. If the trustee were a taker in default whose interest might be seriously affected by appointment, the property subject to the power would apparently be included in his gross estate. It is not clear whether the substantiality of the trustee's interest will be considered significant. Although an insubstantial property interest may disqualify a donee-trustee from immunity, there is no reason to ignore the nature of his interest in determining whether he is a donee at all. Second, even if the trustee has not received a beneficial interest in the property, he may still be considered a taxable donee if he is not "disinterested." For example, to take a very strong case from the Government's point of view, if the trustee or his estate is an object of the power, his control over the devolution is sufficiently potent to regard him as a donee. The Treasury is thus evolving a criterion which smacks a good deal of the substantial adverse interest concept, ${ }^{95}$ and is at the same time more potent. A person who has a stake in the property, be it present or prospective, risks the tax burden imposed upon a donee even though he is not given a power in so many words. $^{96}$ Instead of being treated as a restraining influence, he is regarded as a joint donee. Moreover, he may be a donee even though his interest in the property would not be affected by the appointment. "The regulation permits the inference that a person is not necessarily "disinterested" merely because he lacks a beneficial interest in the appointive property or does not enjoy the possibility of "coming into a good thing." os A parental interest in routing the property to one's children either as appointees or as takers in default might be sufficient, although it does not per se qualify as a substantial adverse interest. ${ }^{93}$

The second example given by the regulations, relating to a power shared by the grantor, also sets a similar implication at large, since the same qualifications are made with respect to the trustee. But there is another element present here, which may be exemplified by a trust creating a life estate for the benefit of the grantor's wife, establishing a remainder in their children, and reserving broad powers of revocation and modifica-

95. See note 87 , supra.

96. It would be extremely unfortunate to hold that a person lacks a power of appointment because of the particular legal phraseology although the control enjoyed by him is that of a donee. The fact that an instrument bestows a power upun $A$, exercicable with the consent of $B$, does not conclusively establish that only $A$ is the dunce. The crux of the matter should be $B$ 's relation to the property and its devolution, not the legal phrasing. Cf. Wisconsin v. J. C. Penney Co., 311 U. S. 435,443 (1940).

97. Compare Commissioner v. Prouty, 115 F. (2d) 331, 336 (C. C. A. 1st, 1940);

G. C. M. 19113, 1937-2 Cuns. BuLr. 151.

98. Compare Commissioner v. Prouty, 115 F. (2d) 331, 336 (C. C. A. 1st. 1940)

99. See Loeb v. Commissioner, 113 F. (2d) 664 (C. C. A. 2d, 1940), ccrt. dcricd, 311 U. S. 710 (1940); Commissioner v. Prouty, 115 F. (2d) 331 (C. C. A. 1st, 1910); cf. Commissioner v. Caspersen, 119 F. (2d) 94 (C. C. A. 3d, 1941), cort. devicd, 314 U. S. 643 (1941). 
tion in the grantor and his spouse. If the grantor dies first the entire property is taxable under section 811 (d) of the Code. ${ }^{100}$ In estate tax theory the settlor is the dominant party of the two, and the wife is merely "another person" amenable to persuasion. ${ }^{101}$ It would therefore be somewhat incongruous to hold that if the wife dies first the trust property should be included in her estate under section 811 (f). The same incongruity would extend to the case of the trustee regardless of whether he is disinterested. However, if the settlor's power terminates tupon the prior death of the person whose consent is required in order to exercise the power, the trust property will escape estate tax unless it is included in the latter's estate. ${ }^{102}$

A related pattern is provided by the joint creation of a trust, revocable or alterable upon the consent of all the settlors, where each settlor brings property into the trust. In this case the decedent's taxable estate includes, by virtue of section $811(\mathrm{~d})$, the share of trust corpus attributable to the decedent. ${ }^{103}$ Here, also, the claim that the decedent is the donee of a power and therefore the entire trust property is includible in his gross estate seems to violate the principle underlying section 811(d) imposing tax upon the co-settlors. But if the trust becomes irrevocable upon the death of one of two settlors, the portion of trust property allocable to the survivor's transfer will escape estate tax unless all the trust property is included in the first decedent's gross estate. ${ }^{104}$ In that event it may seem desirable to

100. This section includes in the decedent's gross estate property transferred by him "by trust or otherwise, where the enjoyment thereof was subject at the date of his death to any change through the exercise of a power (in whatever capacity exercisable) by the decedent alone or by the decedent in conjunction with any other person . . . to alter, amend, revoke, or terminate . . . See Helvering v. City Bank Farmers Trust Ca., 296 U. S. 85 (1935). But cf. Helvering v. Helmholz, 296 U. S. 93 (1935).

101. 296 U. S. at 90, 92. But cf. Estate of Edward Lothrop Ballard, 47 B. T. A. 784 (1942) ; Stephen Hexter, 47 B. T. A. 483 (1942) ; Estate of Frederick S. Fish, 45 B. T. A. 120 (1941).

102. Compare Collins v. United States, 21 Am. Fed. Tax Rep. 1262 (D. Va. 1937). If the "other person" lacks a substantial adverse interest it would seem justifiable to impose a gift tax on the surviving settlor with respect to his contribution because a definitive transfer has occurred as a result of an event which, in accordance with his command, marks the surrender of his dominion over the property. Cf. 2 PauL, op. cit. supra note 7 , at 1139 . But if the "other person" enjoyed a substantial adverse interest upon the creation of the trust, a gift tax would be imposed at that moment since the gift would then be deemed complete. Commissioner v. Prouty, 115 F. (2d) 331 (C. C. A. 1st, 1940); see Higgins v. Commissioner, 129 F. (2d) 237, 241 (C. C. A. 1st, 1942), cert. denied, 317 U. S. 658 (1942). Cf. Reinecke v. Northern Trust Co., 278 U. S. 339 (1929). But $c f$. First National Bank of Birmingham v. United States, 25 F. Supp. 816 (N. D. Ala. 1939).

103. Rrown v. Commissioner, 119 F. (2d) 983 (C. C. A. 7th, 1941); Colonial Trust Co. v. Commissioner, 111 F. (2d) 740 (C. C. A. 2d, 1940); Estate of John Moir, 47 B. T. A. 765 (1942). See Commissioner v. Solomon, 124 F. (2d) 86, 89, n. 8 (C. C. A. 3d, 1941). Cf. George Washington, Sr., C. C. H. 1943 T. C. Serv. 113,021 (T. Ct. mem.). 104. See Collins v. United States, 21 Am. Fed. Tax Rep. 1262 (D. Va. 1937). 
consider him as donee of a power in order to prevent estate tax aroidance with respect to the other's contribution. ${ }^{105}$

The regulations make no mention of a power held by several trustees who are all equally disinterested and have no beneficial interest whatsoever in the appointive property. In this case the criteria which seem to be implicit in the regulations do not seem to be of appreciable assistance. Suppose the trustees are $A, B$, and $C$ and that the power continues until the death of all three. Is the property includible in the gross estate of each, or is some fraction, perhaps one-third, taxable as each dies, or, again, is the entire property taxable to the estate of the last surviving trustee? The statute does not afford any basis for splitting the property into separate taxable portions. If the power were to terminate upon the death of one of the three trustees, this fractional treatment would permit a portion of the assets to escape tax. Nor is it reasonable to assume that the fractional treatment was intended to apply if the power continued but not if the power ceased prior to the death of all three. Hence it seems that the question is whether the property subject to the continuing power should be taxed as each trustee dies or should be included only in the estate of the trustee whose death finally terminates the power.

The raison d'être of the estate tax levy is the cessation of the decedent's interest, rather than the definitive creation of new interests at death. ${ }^{10 i 5}$ It has accordingly been held that section $\$ 11$ (d) applies to a grantor's reserved power to revoke or modify a trust even though a power to revise beneficial interests continues in another person after the grantor's death. ${ }^{\text {nit }}$ The situation is analogous to the creation of a testamentary trust, subject to a power of appointment in the testator's wife. A similar rationale might justify the conclusion that the entire appointive property is included in the estate of each trustee despite the continuance of the power. But one must be wary of a free translation of concepts to other contexts. In the case of a grantor who is taxable under section $\$ 11$ (d), the estate tax

105. See note 102 supra.

106. Compare Riggs v. Del Drago, 317 U. S. 95, 98 (1942); Ithaca Trust Co. v. United States, 279 U. S. 151, 155 (1929); Edwards v. Slocum, 264 U. S. 61, 62 (1924); Y. M. C. A. v. Davis, 264 U. S. 47,50 (1924). But compare the possible implication in Porter v. Commissioner, $28 S$ U. S. 436,444 (1933), referring to the decedent's death as "the source of valuable assurance passing from the dead to the living."

107. See Welch v. Terhune, 126 F. (2d) 695 (C. C. A. 1st, 1942), ccrt. dericd, 317 U. S. 644 (1942) ; Estate of Edward Lothrop Ballard, 47 B. T. A. 784 (1942); Estate of John H. Storer, 41 B. T. A. 1156 (1940). But cf. Fanny MI. Dravo, 40 B. T. A. 309 (1939), aff'd, 119 F. (2d) 97 (C. C. A. 3d, 1941), where the Board held that the decedent's reserved power was not taxable because his surviving brother could reshufle the decedent's dispositions. The decision in Famy .M. Drat'o was distinguished in the Storer case on the ground that the decedent in the latter case could have strielien out the successor power. While Welih v. Terhune cites the Storer ease, it apparently does not rely on this distinction, and the Board itself seems to have abandoned the assertcd distinction in the Ballard case. Compare the Bryant trust in Helvering $v$. Hallods, 309 U. S. 106, 116 (1940); Estate of Peter D. Afidalehauff, 2 T. C. No. 27 (1943). 
reaches the master of the trust. When the estate tax falls due again because of a successor power in another person, it once more applies to a power representing sole control in another. The circumstances are otherwise in the case of the three trustees, since full control is only enjoyed by the last surviving trustee if the power remains until his demise. ${ }^{108}$

Perhaps the answer is revealed in oblique fashion by section 826(d), added to the Code by section 403(c) of the 1942 Act, which entitles the donee's executor to recover from the person "receiving" the property, as a result of the exercise or nonexercise of a power of appointment, a portion of the estate tax attributable to property taxable under section 811(f). Section 826 (d) may rest on the assumption that the appointive property must be freed from any remaining power to route it to others before the duty to contribute arises. ${ }^{109}$ Otherwise the alleged appointee or taker in default might be placed in the unfortunate position of being deprived of his interest after being required to pay a portion of the tax attributed to that interest. ${ }^{110}$ This assumption seems to be strengthened by the fact that the rule of apportionment established by section 826 (d) does not apply if the donee provides his own scheme of incidence. The statute thus purports to offer the donee two alternatives. He may abide by the statutory allocation or fashion his own arrangement. ${ }^{111}$ But there is no such choice where others may redistribute the property, unless it be a choice by sufferance. It is but a short step to an additional assump. tion that taxability occurs under section 811 (f) when the appointive interests are settled beyond recall. However, a similar problem in apportionment would arise in the case of separate successive powers, as where $A$ has a power to appoint the remainder of a trust, followed by a power in $B$, if $B$ survives $A$, and the intermediate life interests have not yet terminated. ${ }^{112}$ Section $826(\mathrm{~d})$ might be understood as merely attempting to apportion the tax burden equitably where equity is possible $^{113}$ and as not determining the taxability of a power. The solution

108. This statement is based on the assumption that all are equally "disinterested."

109. See p. 530 infra.

110. Compare Estate of Sanford v. Commissioner, 308 U. S. 39, 46 (1939). But cf. Robinette v. Helvering, 318 U. S. 184, 186-87 (1943). If the appointee or taker in default eventually received the property after the death of all three trustees and three taxes were imposed, contribution would be required on three different occasions for the receipt of the same property.

111. There are limitations upon the donee's selection of alternatives. See p. 531 infra.

112. Compare Mapleton v. Mapleton, 4 Drew. 515 (ch. 1859). One might complicate the matter by visualizing a power held jointly by three trustees, with successor trustecs joining in as one drops out through death or resignation. Furthermore, if the trustecs were an individual and a trust company, and the power continued in the company after the death of the individual, the failure to impose tax at the latter's death would mean the surrender of all tax on the power since a corporation is not subject to estate tax.

113. A somewhat similar question of apportionment would appear in a case where a donee of a power exercises it by appointing a life estate to his son in conjunction with a 
to the mystery of the three trustees may be aided by the gift tax, which reaches the inter vivos exercise of a power. If all the trustees exercised their power jointly so that the various interests under the trust were finally settled, only one gift tax would probably be imposed. Hence it is reasonable to believe that only one estate tax should be imposed upon a final settlement through death. ${ }^{114}$

\section{Powers to Consume Corpus.}

A statute which proceeds to tax unexercised powers of appointment runs squarely into a dispositive device which has hitherto been scarcely considered in relation to the estate tax, namely, a power to invade corpus. granted usually to a life tenant or to trustees on his behalf. ${ }^{135}$ This device is particularly important where the life tenant is aged or physically unable to support himself. The former language of section sil(f) did not entail any tax consequences where the life tenant might invade principal, since such a power merely lapses at death and unexercised powers were not taxed. Nor, it seems. is such a power taxable under the general language of section $811(\mathrm{a})^{116}$ in view of the decision in Helcering ${ }^{*}$. Safe Deposit \& Trust Company of Baltimore. ${ }^{117}$ But the tax context and consequences have now been altered.

If powers to consume principal are entirely exempt from estate tax, the value of the amendments is seriously impaired. Instead of creating a general "power of appointment" as usually understood by conveyancers, a settlor or testator might create an unrestricted right to dip into corpus,

power in the son to appoint the remainder. However, if apportionment is impassible here, the fault lies with the first donee since he created the uncertainty hovering over the remainders. Still another case is represented by life estates for $A$ and $B$ and the survivor of them, with a power of appointment exercisable jointly or by the survivor.

114. This result might lead to a skipping of estate tax in the following siturtion: 1 and $B$ are trustees, endowed with broad powers of amendment, exercisable jointly or by the survivor while the life estates are outstanding. $A$ dies before the remainder falls in and the power continues in $B$. There is no estate tax with respect to $A$. Thereater the life estates terminate before $B$ 's death. Hence there is also no estate tax with respect to $B$. It seems, however, that he might be liable for gift tax for he has, in effect, released the power by permitting it to lapse without exercising it during the period allotted for such exercise.

115. See 1 PAur, op. cit. supra note 7, \$4.12; Dicus, Taxabilily of Rights of Withdrazual under Federal Estate Tax (1939) 17 ChI-Kext. L. Rev. 209. From a non-tax point of view, see Whiteside and Edelstein, Life Estales ruith Poucr to Constsme: Rights of Creditors, Purchasers and Renaindernen: A Study of New Lorl: Real Proferty Lazv Sections 149-153 (1931) 16 CoRN. L. Q. 447.

116. Estate of Gertrude Leon Royce, 46 B. T. A. 1090 (1942). Cf. Edith Evelyn Clark, 47 B. T. A. 865 (1942).

117. 316 U. S. 56 (1942). See Eisenstein, supra note 1, at 338. If there is nu gift over of the principal and the trustee is accordingly required to distribute remaining principal to the life tenant's estate, see 1 Restatexrent, Trusrs (1935) $\$ 12 \$$, comment $c$, to the effect that the principal should be taxable under (a). 
the remainder passing to specified persons. Now there is obviously no substantial difference between a general "power of appointment" and such a power of invasion. As Mr. Paul has indicated, the holder of an unrestricted power to appropriate principal "enjoys the basic delights of ownership. If he exercised the power, the property would become his and pass as part of his estate. His decision determines whether the property is to pass to the appointed remaindermen." 118 It may be that in the past tax avoidance by means of this device has been comparatively infrequent. But if the statute is redrawn to reach unexercised powers, all potential methods of impairing the effectiveness of the statute must be nullified within reasonable limitations. Once it is indicated that a power to invade principal is a genuine loophole, this route to avoidance woutd probably become quite popular. The fact that a power of invasion is an assurance of desirable flexibility is not conclusive. If all powers of appointment were viewed entirely in terms of flexibility in the final distribution of one's wealth, they would never run the gauntlet of an estate tax. ${ }^{110}$

The committee reports reflect the broad purpose of reaching all powers, whether or not they are "powers of appointment" in the usual technical property sense. As the reports put it: "The term 'power of appointment' includes all powers which are in substance and effect powers of appointment regardless of the nomenclature used in creating the power and local property law connotations." 120 Hence if a life tenant may help himself at will to the underlying principal, the corpus remaining at his death should be subject to estate tax, even if such a power is not generally characterized as a power of appointment in the law of property. ${ }^{121}$ The life tenant enjoys all the attributes of ownership except the formal trappings of title. According to the regulations, "if a settlor transfers property in trust for the life of his wife, with a power in the wife to appropriate or consume the principal of the trust, the wife has a power of appointment." 122

118. See 1 PAUL, op. cit. supra note 7, at 223.

119. The same immunity would be accorded life insurance if considered exclusively as a "pressing social duty." Burnet v. Wells, 289 U. S. 670, 681 (1933). See H. R. Rep. No. 767, 65th Cong., 2d Sess. (1918) 22 (1939-1 Cum. Bul.., Pt. 2, pp. 101-02).

120. H. R. Rep. No. 2333, 77th Cong., 2d Sess. (1942) 160; SEN. Rep. No. 1631, 77th Cong., 2d Sess. (1942) 232. Compare the broad concept of a taxable gift emphasized in H. R. Rep. No. 708, 72d Cong., 1st Sess. (1932) 27 (1939-1 Cux. Bull., Pt. 2, p. 476); Sen. Rep. No. 665, 72 d Cong., 1st Sess. (1932) 39 (1939-1 Cun. Bull., Pt. 2, p. 524); Smith v. Shaughnessy, 63 Sup. Ct. 545, 547 (U. S. 1943); Commissioner v. Beck's Estate, 129 F. (2d) 243, 244 (C. C. A. 2d, 1942); Commissioner v. Marshall, 125 F. (2d) 943,945 (C. C. A. 2d, 1942).

121. Compare 3 Restatement, Property (1940) $\$ 323(\mathrm{~b})$, to the effect that a life tenant "may also have a general power of appointment presently exercisable over the remainder and a power to appropriate, sell or consume any part thereof." See also id. $\S 318(2)$ and comment $j$, where it is declared that a power to augment income, whether or not restricted, is not commonly known as a power of appointment.

122. U. S. Treas. Reg. 105, $\$ 81.24$ (b) (1). Cf. Ill. Laws 1943, p. 59, $\$ 1(a)$. 
Undoubtedly a tax on powers of invasion will seriously affect the internal structure of family settlements. The power may no longer be given to a beneficiary, unless one is willing to augment the estate tax revenues. However, here again, as in other aspects, the statute pays due respect to the needs of familial flexibility without impairing its basic frameworls. It allows sufficient scope for the tax-free use of such powers if entrusted to others, since the provisions exempting two types of powers are equally applicable here. ${ }^{123}$ There is no tax, for example, if a son may invade corpus for the benefit of his mother pursuant to a trust indenture created by his father. ${ }^{124}$ "Similarly, even if there is no exemption on the basis of relationship, immunity is still possible if the power is conferred upon a person who has no beneficial interest in the property. The puwer may thus reside in persons who would in all probability be very susceptible to requests for more corpus. ${ }^{125}$ Where an exemption is sutglit ly entrustings the power to a disinterested trustee, it is necessary to make certain that he has no vested or contingent interest in the property and that he has no power to appoint in favor of himself, his estate. his creditors, or the creditors of his estate. If the trustee has a remote contingent interest in

123. It has been suggested that a literal reading of section $811(f)(2)(A)$ allows a tax-free power in the donor's wife to consume corpus. See Browne, Paccirs of Appointment as Affected by the Fediral Rerente Aft of 1042 (1942) 22 Truss ButL. 2, 4. Cf. Alexander, Taxation of Pouiers of Appointment Under the Rerenus .At of 1042 (1943) 56 HARr. L. REv. 742, 754, n. 62. This section describes the exempt elass ur relatives as "the spouse of the decedent, spouse of the creator of the puwer, descendants of the decedent or his spouse, descendants (other than the decedent) of the ereator of the power or his spouse, spouses of such descendants." The argument is that the parenthetical phrase excludes the donee only as a descendant of the donor, but nit as a spouse of the donor. But this argument proves too much. The statute makes no distinctiun between a power to consume corpus and the technical power of appointment. It would thereiore have to be argued that a power in the donor's widow to anpuint to herself by deed-the most general of general powers-is free from tax although such a donee may abvicusly appoint to anyone she pleases. But $c f$. U. S. Treas. Reg. 105, $\$ 81.24(b)(2)$. Such a power would obviously not be limited to the group of relatives mentiuncd in seetiun S11(f)(2) (A). The same "literal" interpretation would require a livlding that if the daughter-in-law of the creator of a power may appoint to herself she nevertheless has a tax-free power, whereas if the daughter-donee may appuint to herseli the power is tasable. The parenthetical phrase seems to reflect merely an excess of caution and dies not obscure the intention of destroying all tax immunities enjoyed by the general puwer. Cf. Harrison v. Northern Trust Co., 317 U. S. 476, 479-80 (1943); United States v. American Trucking Associations, 310 U. S. 534, 543 (1940); Helvering v. Nev Yorl: Trust Co., 292 U. S. 455, 464 (1934).

124. The above example would hold true even if the sun were the remainderman. If he died before his mother there would be no estate tax as a result of the puwer, since at death he would have no power to appoint himself. Obviously if the remainder passed as part of his estate, there would be a tax under section S1Ifa). See 1 PAUL, of cir. supra note $7, \$ 4.09$.

125. Compare Blunt v. Kelly, 41 F. Supp. 721, 723 (D. N. J. 1941), aff'd, 131 F. (2d) 632 (C. C. A. 3d, 1942). 
the property he incurs the risk of estate tax, and also gift tax if he releases the power during his lifetime or makes payments of principal. ${ }^{120}$

Although the statute provides that a power is immune from tax if specified conditions are met, settlors and their legal advisers should be wise enough to realize that compliance with the bare words of a statute does not necessarily gain the desired freedom from tax. ${ }^{127}$ The composite picture may nevertheless reveal a distortion of the statutory purpose. ${ }^{128}$ For example, if a life tenant may at will remove a disinterested trustee who has unfettered discretion to pay over corpus to him, and appoint another trustee who will possess the same power, it may reasonably be inferred that the life tenant has an unlimited power to invade corpus for his own benefit because he is free to appoint a compliant trustee. On the other hand, the strength of this inference might be seriously weakened if the consent of the remaindermen, whose estate would necessarily be diminished if corpus were appropriated, were necessary in order to remove the trustee or appoint a new one. All relevant data would have to be considered. If the consent of a number of persons were requtired, including that of the remaindermen, there would obviously be little scope for avoidance. At any rate the statute does not purport to reach a mere power to remove a trustee.

All discussion thus far has proceeded on the assumption that under the terms of the trust one may freely help one's self or another to principal. ${ }^{120}$ An additional problem arises where the power to invade is subject to the careful scrutiny of a court of equity and the invasion may not exceed judicially enforceable standards. For example, the settlor may provide a specified income for his wife and permit the appropriation of sufficient principal to offset any deficiency in income. Again, the settlor may sanction the use of corpus for the life tenant's "comfort and support," a type of provision which may or may not create an enforceable standard. ${ }^{130}$

126. See p. 534 infra.

127. Compare the now classic example of Gregory v. Helvering, 293 U. S. 465 (1935).

128. See, generally, Radin, $A$ Short Way with Statutes (1942) 56 FInRv. L. Rev. $388,398$.

129. Compare In re Ryder, [1914] 1 Ch. 865, and In re Richards, [1902] 1 Ch. 76, with Re Fox, 62 L. T. 762 (Ch. 1890), and Re Pedrotti's Will, 27 Beav. 583 (Ch. 1859).

130. This question of an enforceable limitation upon the life tenant's power to consume principal arises frequently in connection with the deduction allowed for contributions to charity. Compare Ithaca Trust Co. v. United States, 279 U. S. 151 (1929) ; Commissioner v. Bank of America National Trust \& Savings Ass'n, 133 F. (2d) 753 (C. C. A. 9th, 1943) with Commissioner v. Merchants National Bank of Boston, 132 F. (2d) 483 (C. C. A. 1st, 1942), cert. granted, 63 Sup. Ct. 1031 (U. S. 1943); Gammons v. Hassett, 121 F. (2d) 229 (C. C. A. 1st, 1941), cert. denied, 314 U. S. 673 (1941); Springfield Safe Deposit \& Trust Co. v. Hassett, 43 F. Supp. 401 (D. Mass. 1942); see Helvering v. Union Trust Co., 125 F. (2d) 401, 403 (C. C. A. 4th, 1942), cert. denied, 316 U. S. 696 (1942); discussion in 1 PAUL, op. cit. supra note 7, $\$ 12.26$. Cf. Hess and Guterman, supra note 39 , at 341. 
Assuming, however, that the power of invasion is governed by a standard, the question is whether tax may be imposed if the power is not otherwise exempt. Under such circumstances it seems to be correct to hold that the power is taxable to the extent that the decedent may, at his death, dip into principal to bring the income yield up to the income standard. For example, if the trust has yielded an income of $\$ 20,000$ for the year terminating shortly before the death of the life tenant, the income standard of the trust is $\$ 30,000$, and the decedent at the moment of death may dip into corpus to obtain an additional $\$ 10,000$, there would be a power to invade corpus to the extent of $\$ 10,000{ }^{131}$ Possible future resort to corpus should not enter into the calculation since the power is contingent with respect to all subsequent years. Death. moreover, has fully disclosed that the contingency will never materialize. If a decedent's contingent remainder which is obliterated by his death is not included in his gross estate, a similarly contingent power should not fare worse. ${ }^{132}$

\section{Collateral Changes}

\section{Appointments and Gifts in Default to Charity}

Under the former statute it was uncertain whether property appointed under a general power to a charity within the meaning of section 812 (d) or 861 (a) (3) was deductible as a bequest, devise, legacy or transfer to charity. ${ }^{133}$ A statute which treats the donee of a power as owner for purposes of taxation should certainly treat hin as owner for purposes of the available deductions. "Once his quasi property, always his quasi property." ${ }^{134}$ The 1942 Revenue Act carries out this policy and permits the deduction if the property passes to charity by appointment or as a re-

131. If the life tenant irrevocably waives his right to consume principal in a particular year he should be liable for gift tax, with due consideration of his enjoyment of the income to be yielded by the undisturbed principal. Such waiver may occur by virtue of a failure to invade within the time stipulated in the trust instrument. The waiver may be treated as a release intended to take effect at death. See further nute $195 \mathrm{i}: \mathrm{fra}$.

132. See note 21 , supra. While the power may be measurcd by some standard such as illness or emergency, the contingencies may be so many and so broad as to amount to an outright power of invasion. Cf. Mary E. Wenger, 42 B. T. A. 235 (1940), af 'd, 127 F. (2d) 523 (C. C. A. 6th, 1942), cert. denict, 317 U. S. 646 (1942); Helvering v. Evans, 126 F. (2d) 270 (C. C. A. 3d, 1942), cert. denied, 317 U. S. 638 (1942). If the occurrence of the contingency is within the control of the life tenant, it may reasonably be held that he has an immediate power. Cf. 2 PAur, op. cit. supra note 7, at 1137. At any rate, one should look to the life tenant's right as of the moment of death, and the measurement of such right may well entail the diffcult task of determining how the local court would have reacted to a request for principal. See generally, 1 RESTATEas:it. TRUSTS (1935) $\S 128$, comments $d, \varepsilon$, and $\S 187$.

133. See 1 PaUl, op. cit. supra note 7, \$9.04; Griswold, supra note 47, at 950 . ( $\%$. Thompson v. Pew, 214 Miass. 520, 102 N. E. 122 (1913) (lapse statute).

134. 1 PAUL, op. cit. supra note 7 , at 422 . 
mainder in default of appointment. ${ }^{135}$ Rules governing charitable deductions are thereby made applicable to appointive assets, the decedent-donec being treated as owner. ${ }^{136}$ The committee reports state, in addition, that the "amendment is clarifying with respect to property passing to charity under a general power of appointment exercised by the decedent and includible in the gross estate." ${ }^{137}$ If the power itself is not taxable the amendment does not function, since the assets passing to charity are not includible in the gross estate.

\section{Property Previously Taxed}

Another deduction allowed in computing the estate tax is the value of any property subject to estate or gift tax within five years prior to the death of the decedent, "where such property can be identified as having been received by the decedent from the donor by gift, or from such prior decedent by gift, bequest. devise, or inheritance, or which can be iden-

135. Pub. L. No. 753, §403(b).

136. See U. S. Treas. Reg. $105, \S 81.44$, as amended by T. D. 5239, 1943 INT. REv. Bulc. No. 6, 213. A deduction should therefore be allowed where the donee of a power exercises it by appointing to charity, subject to a power in a designated individual to allocate the property among different institutions. Cf. St. Louis Union Trust Co. v. Burnet, 59 F. (2d) 922 (C. C. A. 8th, 1932) ; Beggs v. United States, 27 F. Supp. 599 (Ct. Cl. 1939). However, in accordance with the law governing charitable dispositions by owners of property, the appointment to charity may not be subject to a power in another to divert to private purposes, Knoernschild v. Commissioner, 97 F. (2d) 213 (C. C. A. 7th, 1938) ; Davison v. Commissioner, 81 F. (2d) 16 (C. C. A. 2d, 1936) ; Girard Trust Co., 41 B. T. A. 157 (1940), rev'd on other grounds, 122 F. (2d) 108 (C. C. A. 3d, 1941), unless the other person renounces the power within the time allowed for filing the estate tax return and the property consequently passes to charity. Pub. L. No. 753, \& 408, amending $\$ \$ 812$ (d), 861 (a) (3). Compare the confused opinion in Norris v. Commissioner, 134 F. (2d) 796 (C. C. A. 7th, 1943). However, if the property is designated for private purposes, and another person is authorized to divert the property to charity, no deduction is allowed. Burdick v. Commissioner, 117 F. (2d) 972 (C. C. A. $2 d$, 1941), cert. denicd, 314 U. S. 631 (1941) ; cf. First Trust Co. of St. Paul v. Reynolds, 46 F. Supp. 497 (D. Minn. 1942). But compare the decisions in Commissioner v. First National Bank of Atlanta, 102 F. (2d) 129 (C. C. A. 5th, 1939); Dimock v. Corwit, 99 F. (2d) 799 (C. C. A. 2d, 1938), aff'd, 306 U. S. 363 (1939); Mead v. Welch, 95 F. (2d) 617 (C. C. A. 9th, 1938) ; Humphrey v. Millard, 79 F. (2d) 107 (C. C. A. 2d, 1935); Estate of Dudley S. Blossom, 45 B. T. A. 691 (1941). Furthermore, if property is appointed to charity, which pays a portion thereof to a private taker in default in compromise of a contest over the validity of the appointment, the deduction should be limited to the amount retained by charity. Thompson's Estate v. Commissioner, 123 F. (2d) 816 (C. C. A. 2d, 1941) ; Estate of Sage v. Commissioner, 122 F. (2d) 480 (C. C. A. 3d, 1941), cert. denied, 314 U. S. 699 (1942) ; E. T. 17, 1940-1 Cum. BuLl. 231; cf. Robbins v. Commissioner, 111 F. (2d) 828 (C. C. A. 1st, 1940). Contra: Continental Illinois Nat. Bank \& Trust Co., 38 B. T. A. 220 (1938), which is now in effect overruled. For a discussion of the content of "charity," see 1 PAUL, op. cit. sulpra note 7, c. 12.

137. H. R. Rep. No. 2333, 77th Cong., 2d Sess. (1942) 161; Sen. Rer. No. 1631, 77th Cong., 2d Sess. (1942). 
tified as having been acquired in exchange for property so received." $13 s$ Prior to the enactment of the 1942 Act there was no specific reference to powers of appointment. ${ }^{139}$ It is now provided. however, that property included in the gross estate of the prior decedent under section 811 (f) is deductible as previously taxed property. ${ }^{140}$ There is no express provision that the estate of the decedent-donee of the power is entitled to the deduction when the power was bestowed upon him within the applicable five-year period. But the words "gift. bequest, devise" may be broad enough to include a power to appoint property received from another person. However, in the case of a taxable power held by several trustees, the power continuing until the death of all, the statute does not seem broad enough to protect the trustees other than the first to die, assuming that their deaths occur at intervals of five years.

\section{Apportionment}

An estate tax on special powers must in all fairness provide for the allocation of a proportionate share of the tax burden to the appointive assets. The increase in taxable assets as a result of a power which is not exercisable for the direct benefit of the donee may drastically affect the rate bracket. ${ }^{141}$ And in the absence of an apportionment provision the entire tax is payable out of the donee's individual estate, ${ }^{1 / 2}$ which may be completely depleted. ${ }^{143}$ The amendments with respect to powers there-

138. The deduction is subject to various qualifications in the governing sections. Sce $\$ \$ 812$ (c) and $\$ 61$ (a) (2), as amended by Pub. L. No. 753, $\$ \$ 405$ (b) (c) and 407.

139. This omission is not necessarily fatal. Cf. Commissioner v. Fletcher Savings \& Trust Co., 59 F. (2d) 508 (C. C. A. 7th, 1932), holding that for the purpose of section 812 (c) property is acquired by "inheritance" where the surviving spouse of a tenancy by the entirety succeeds to sole ownership. See, further, G. C. MI. \$481, X-1 Cu:r. BuLL. 451 (1931).

140. Section 407. See U. S. Treas. Reg. 105, $\$ \$ 1.41$ (a)(1). It is not clear whether this provision is merely declaratory of prior law in the case of property passing under an exercised general power. It seems that if the amendment relating to charitable deductions is declaratory in such a case, the same should be true of Pub. L. No. 753, $\S 407$.

141. See, e.g., Whitney v. State Tax Comm., 309 U. S. 530 (1940).

142. See Dexter v. Jackson, 245 Miass. 333, 140 N. E. 267 (1923); cf. Matter of Rogers, 249 App. Div. 238, 291 N. Y. Supp. $\$ 15$ (2d Dep't 1936), motion for lcaze to appeal denied, 273 N. Y. 680 (1937), 50 HARv. L. Rev. S44. See Pennsyluania Co. for Insurances on Lives v. Lederer, 292 Fed. 629, 630 (E. D. Pa. 1921). The decision in Riggs v. Del Drago, 317 U. S. 95 (1942), indicates that this rule is not implicit in the federal estate tax law. See also Harrison v. Northern Trust Co, 317 U. S. 476,479 (1943).

143. See Highfield v. Delaware Trust Co., 34 Del. 306, 313-14, 152 Atl. 124, 127-28 (1930). It has been suggested that section $811(f)$ might be held invalid as to special powers if an apportionment provision were omitted. See Comment (1943) 36 Han: L. REv. 428,453 . While the lack of such a provision would induce unwarranted hardship, it is doubtful whether invalidity would necessarily follow. Whitney v. State Tas Comm., 309 U. S. 530 (1940), sustaining an estate tax on special powers, did not allude to any need for apportionment. Cf. Lewellyn v. Frick, 208 U. S. 238, 251 (1925). 
fore provide that unless the decedent-donee directs otherwise in his will, the executor is "entitled to recover from the person receiving such property by reason of the exercise, nonexercise, or release of a power of appointment such portion of the total tax paid as the value of stich property bears to the sum of the net estate and the amount of the exemption allowed in computing the net estate, determined under section 935(c), or section $861,,^{144}$ as the case may be." ${ }^{145}$ This provision is entirely compatible with local statutes which allocate the tultimate incidence of the tax "as to properties actually handled as part of the estate by the executor." 146

Prior to the 1942 Act the only federal provision directing apportionment of tax related to life insurance proceeds payable to a specific beneficiary. ${ }^{147}$ The portion of tax payable out of the proceeds was determined by the ratio of the taxable proceeds to the net estate. A literal application of this formula deprived the insurance beneficiary of a pro rata portion of the specific exemption allowed in computing the over-all tax and it was not clear whether the language was sufficiently elastic to allow the intrusion of equitable considerations. ${ }^{148}$ This situation has now been corrected in the life insurance provision, ${ }^{140}$ and the revised ratio is equally applicable to powers of appointment. ${ }^{150}$ Thus if the appointive assets are worth $\$ 200,000$, the net estate is valued at $\$ 940,000$, and the estate tax is $\$ 303,500$, the appointive assets must contribute $1 / 5$ of the tax, or $\$ 60,700$, since the percentage is determined by the ratio of $\$ 200,000$ to the sum of $\$ 940,000$ plus $\$ 60,000$, the specific exemption.

The formula of apportionment does not attribute the appointive property entirely to the higher rate brackets. In the example given above the

144. Section 935 (c), as amended by Pub. L. No. $753, \S 414$, grants a $\$ 60,000$ specific exemption for purposes of the additional estate tax, and section 861 , as amended by Pub. L. No. 753, $\S 412$, allows a $\$ 2,000$ specific exemption to estates of nonresident aliens.

145. Pub. L. No. $753, \S 403$ (c), adding to section 826 a new subsection (d). It is further provided that "if there is more than one such person the executor shall be entitled to recover from such persons in the same ratio." The language of the section constitutes a clarification of the House Bill.

146. Riggs v. Del Drago, 317 U. S. 95, 102 (1942). There seems to be an implication here that local apportionment statutes do not apply to property subject to powers of appointment. See also id. at 98-99.

147. Section 826(c).

148. Compare United States Trust Co. of New York v. Sears, 29 F. Supp. 643 (D. Conn. 1939); and see discussion in 1 PAUL, op. cit. supra note 7, §13.55; Karch, The Apportionnient of Death Taxes (1940) 54 Harv. L. Rev. 10, 27.

149. Pub. L. No. 543, §404. See Sen. Rer. No. 1631, 77th Cong., 2d Sess. (1942) 236.

150. Section 403 (c) of the House bill adopted the revised formula, but no correlative change was made with respect to life insurance. The Senate made the necessary correction as to insurance, and made technical changes in the section on powers so as to coordinate both apportionment provisions. See SEN. REP. No. 1631, 77th Cong., 2d Sess. (1942) 233-34; Conf. Rep. No. 2586, 77th Cong., 2d Sess. (1942) 69 (Amendment No. 398). 
decedent's personal assets are ultimately liable for a tax burden of $\$ 242,800$, whereas the burden upon such property if it comprised the entire net estate would be $\$ 229,700$. Under the formula all the taxable assets are deemed to contribute the same amount of tax burden per unit value. There is nothing arbitrary in this rationale. ${ }^{151}$ It is no more correct to say that a particular item of property is responsible for the highest estate tax bracket than it is to say that a particular item of taxable income is responsible for the highest income tax bracket. ${ }^{172}$. All items of taxable property are simply added together to make one numerical total upon which the tax is imposed. ${ }^{153}$ Appointive property should not be treated as a separate taxable unit in the estate, for from the estate tax point of view such property is as much the decedent's as any other included in the taxable estate, as, for example, property owned by the entirety and life insurance, particularly where the decedent did not pay the premiums but possessed an incident of ownership at death. Moreover, if the highest brackets were attributed to the appointive property, the fund to be received by the appointee or taker in default might be virtually depleted. ${ }^{13}$

The apportionment provision raises a number of problems. For example, suppose a trust provides that the income is to be paid to $A$ and $B$ during their joint lives, and thereafter to the survivor, and that $A$ has a power to appoint the remainder. Assume further that $A$ predeceases $B$ and appoints the remainder to $C$ and $D$. Section $\$ 26$ (d) provides that $A$ 's executor may recover a specified portion of the tax "from the person receiving such property by reason of the exercise, nonexercise, or release of a power of appointment." The question in this case is whether the appointees have "received" the property at the time of $A$ 's death. ${ }^{165}$ The word "receiving" may be read very narrowly to mean actual enjoyment of the property by the appointee. In that event $A$ 's executor would not be able to seek reimbursement until the termination of $B$ 's life estate. But this interpretation may sacrifice the evident purpose of reimbursing the

151. But $c f$. Alexander, supra note 123, at 753 .

152. Compare, however, Finance Act, 1922, 12 \& 13 Geo. V., c. 17, \$20(2) (3) (4).

153. "Since the tax is measured by the total transierred to one or many, cach pays a tax measured, not by the benefit he receives, but in sume degree by the benefit others receive." Matter of Vanderbilt, 281 N. Y. 297, 316, 22 N. E. (2d) 379, 390 (1939), aff'd sub nom. Whitney v. State Tax Comm., 309 U. S. 530 (1940). See also 1 Paud, op. cit. supra note 7 , at 781,783 .

154. Thus, under the facts in the above example, the appointive property would be liable for $\$ 73,800$ of the tax, or the difference between a total tax of $\$ 303,500$ on a net estate of $\$ 940,000$ and a total tax of $\$ 229,700$ on a net estate of $\$ 740,000$. The disproportionate burden cast upon the appointive property would be augmented as the proportion of individual assets to total assets increased.

155. The problem would be similar where the property was allowed to pass to the takers in default. If the donee has a general power he may appoint the property to his executor, who may dispose of it for the purpose of satisfying the burden allocated to the property by section 826 (d). 
donee's estate for taxes attributable to appointive property and seriously affect the shares bequeathed out of his individual estate. Moreover, the executor might be placed in the unhappy position of being required to keep the estate open for a number of years. ${ }^{156}$ The policy of the provision might be more appropriately fulfilled by a holding that "receiving" refers to the acquisition of a right to property, present or future, which may not be destroyed or diverted by the act of another person. ${ }^{\mathbf{1 5 7}}$ This interpretation, however, would not obviate all difficulties. Thus, in the example above, $C$ and $D$ would be required to contribute a portion of the tax to the executor before actual enjoyment of the property. ${ }^{108}$ Furthermore, either appointee might die after reimbursing the executor and before his remainder vests in enjoyment, with the result that his share would ultimately pass to another person designated by the donee as an alternate taker. ${ }^{150}$

156. Consider, for example, a case where the donee appoints a life estate in $A$, with remainder in $B$. The donee's executor would have to await the death of $A$ in order to obtain reimbursement from $B$. This practical factor should be given weight in interpreting section 826(d). Cf. Learned Hand, J., concurring in Thomas v. Commissioner, 100 F. (2d) 408, 411 (C. C. A. 2d, 1938). "Expediency may tip the scales when arguments are nicely balanced." Woolford Realty Co. v. Rose, 286 U. S. 319 (1932), 330. An alternative possibility might be to treat the trustee as "receiving" the property in this casc. But this view does not harmonize very well with the provision in section 827 (d) that "if there is more than one such person entitled, the executor shall be entitled to recover from such persons in the same ratio." Furthermore, in the case considered in the text the executor would not be able to get recoupment from the trust, apart from the fact that the trustee does not receive the property by virtue of the exercise of the power, as long as $B$ 's life estate continued, for otherwise $B$ 's interest would be impaired and he would in effect contribute. Finally, apportionment is an effort to do justice among those persons who receive beneficial interests in property and "person" probably refers to such recipients. Cf. Helvering v. Hutchings, 312 U. S. 393 (1941).

157. Compare Smith v. Shaughnessy, 318 U. S. 176 (1943) ; Robinette v. Helvering, 318 U. S. 184 (1943) ; United States v. Frank, 133 F. (2d) 1009 (C. C. A. 7th, 1943); Commissioner v. McLean, 127 F. (2d) 942 (C. C. A. 5th, 1942); Commissioner v. Marshall, 125 F. (2d) 943 (C. C. A. 2d, 1942), dealing with a somewhat analogous problem in gift taxation. The interpretation suggested seems to be strengthened by the fact that in section 827(b) personal liability for the tax is imposed on the "person in possession of the property by reason of the exercise, nonexercise, or release of a power of appointment."

158. Compare $\$ \$ 925-27$, providing for a postponement of estate tax attributablc to the inclusion in the gross estate of a future interest.

159. It may be that the contingent remainderman would also be required to contribute. But he may find himself in the predicament of contributing a portion of the tax and never receiving the property itself. Cf. Goodwin v. McGowan, 47 F. Supp. 798 (W. D. N. Y. 1942), where the taxpayer was held liable for a gift tax upon the value of a contingent remainder which disappeared after his transfer thereof. Local apportionment statutes surmount many of the problems created by trusts by providing for the payment of the tax allocable to the trust property out of its corpus without apportionment as among the various trust interests. N. Y. Decedent Estate Law $\$ 124$; Pa. Stat. Ann. 
Section 826(d) states that the formula provided to allocate the tax applies "unless the decedent directs otherwise in his will." ${ }^{109}$ Does this proviso override the local law governing the scope of the donee's diseretion, or the donor's directions as to payment of tax attributable to the appointive property? For example, the donee of a tavable special power may desire to redistribute the tax burden by forcing the appointive property to pay the tax imposed by the higher brackets applicable to his estate. Or a donor may have provided that the appointive property is to pass unscathed by any death taxes, and that the donee shall pay the entire tax out of his individual property.

Insofar as local law is concerned, it seems that section $826(d)$ of the federal statute, except for its own rule of apportionment, leaves it where it finds it. ${ }^{101}$ This section is designed to relieve the donee of a special power from the misfortune of bearing a tax burden which he cannut satisfy out of the property producing the burden. ${ }^{102}$ There is no intention to expand the area of such a donee's appointive discretion as established by the donor, especially since an increase in the portion of tax required to be paid out of the appointive property might be an unreasunable reshuffling of the respective tax burdens. However, since the donee, by remaining silent, would subject the appointive property to the formula established by section $826(d)$, there is no reason why he may not lessen the burden otherwise attributable to such property by an explicit direetion in his will. Furthermore, a testamentary provision to this effect should be valid even if the donee's power is exercisable only by deed.

The donor's direction that the donee pay the entire tax would, un the other hand, probably not prevent the latter's estate from involing section $826(\mathrm{~d})$. Any argument to the effect that the donee accepted the power subject to a stated condition as to tax liability is not persuasive. One might just as well contend that the donee of a special power accepted it with the understanding that no part of the appointive property could be diverted for purposes beyond the scope of the power. On the other hand,

(Purdon, Supp. 1941) tit. $201 \S 844$; R. I. Laws 193S, c. 43, as amended by Laws 1939, c. 664 .

Another problem to be considered is that arising frum a comprumise between the takers in default and the appointees so that the appuintment is recugnized in part. In such case the takers in default would probably be reguired to cuntribute on the gruund that their position is similar to that of remaindermen receiving property as a result of the donee's deliberate failure to appoint. Cf. Helvering v. Safe Depusit \& Trust $C u$. ui Baltimore, 316 U. S. 56 (1942).

160. The New York apportionment statute, Decenenr Estare Law $\$ 124$, pruvides that its rule of apportionment does not govern "in a case where a testatur utherwise directs in his will" or "in a case where by written instrument executed inter vivos direetion is given for apportionment within the fund of tases assessed upon the spacific fund dealt with in such inter vivos instrument."

161. Compare Comment (1943) 56 HaRv. L. Rev. 428, 453, n. 186.

162. See Comment (1929) 42 Harv. L. Rev. 419. 
the donor may provide that the tax attributable to the appointive property at the donee's death shall be satisfied out of the former's property. ${ }^{103}$ In this case the formula of section 826(d) should not apply, at least to the extent that the donor or his estate is able to pay the tax, since the purpose of the statute is to relieve the donee, and not the donor who assumes the tax liability.

A number of other questions may be briefly noted. For example, if the appointive assets are includible in the gross estate and then deductible because they pass to charity, must the charity pay an allocable portion of the tax? It seems fair to hold, as one court indicated with respect to life insurance, ${ }^{164}$ that since the assets passing to charity do not contribute to the tax burden, they should not be subjected to the rule of apportionment. ${ }^{105}$ However, the problem becomes more difficult where the assets are appointed in trust, so that the charity's receipt of the property must await the termination of a life estate. If all the tax attributable to the intervening estate is payable out of the life tenant's interest in the property, the purpose of the trust may be severely mutilated. ${ }^{100} \mathrm{~A}$ similar question is presented by a gift to charity subject to an annuity for a private beneficiary. ${ }^{167}$ The proper allocation of tax incidence where a charity is involved is important for the additional reason that it affects the amount of estate tax due from the estate as a whole. ${ }^{168}$ These are prob-

163. Compare Matter of Duryea, 277 N. Y. 310, 14 N. E. (2d) 369 (1938).

164. See Commissioner v. Pupin's Estate, 107 F. (2d) 745, 746 (C. C. A. 2d, 1939); cf. Matter of Starr, 157 Misc. 103, 282 N. Y. Supp. 957 (Surr. Ct. 1935) ; Wilkinson's Estate, 37 Pa. D. \& C. 243 (1940). But cf. Estate of Bernays, 7 So. (2d) 444 (Fla. 1942).

165. It is assumed that the decedent-donee has not directed that tax be paid out of the appointive property.

166. See Morristown Trust Co. v. Childs, 128 N. J. Eq. 524, 17 A. (2d) 559 (1940). Compare Grainger's Ex'rs \& Trustees v. Pennebaker, $247 \mathrm{Ky} .324,56 \mathrm{~S}$. W. (2d) 1007 (1932) ; Commonwealth-Merchants Trust Co. v. Seglie, 127 N. J. Eq. 160, 12 A. (2d) 153 (1940); Gates v. Plainfield Trust Co., 121 N. J. Eq. 460, 191 Atl. 304 (1937), aff'd, 122 N. J. Eq. 366, 194 Atl. 65 (1937) ; In re Diehl's Executor, 88 N. J. Eq. 310, 102 Atl. 738 (1917), aff'd, 89 N. J. Eq. 209, 103 Atl. 322 (1918) ; Title Guarantee \& Trust Co. v. Lohrke, 102 Atl. 660 (N. J. Ch. 1917) ; Matter of Tracy, 179 N. Y. 501,72 N. E. 519 (1904); Wachovia Bank \& Trust Co. v. Lambeth, 213 N. C. 576, 197 S. E. 179 (1938); Wellman v. Cleveland Trust Co., 107 Ohio St. 267, 140 N. E. 104 (1923), with Brown's Estate, 208 Pa. 161, 57 Atl. 360 (1904) ; Penn-Gaskell's Estate (No. 1), 208 Pa. 342, 57 Atl. 714 (1904) ; Crane's Estate, 314 Pa. 193, 170 Atl. 284 (1934); Henris's Estate, $53 \mathrm{~Pa}$. Super. 633 (1913).

167. See the principle of allocation employed in Matter of Tracy, 179 N. Y. 501, 72 N. E. 519 (1904) ; In re Kaegebehn, 16 N. J. Misc. 388, 1 A. (2d) 56 (Orphans Ct. 1938) ; Minot v. Winthrop, 162 Mass. 113, 38 N. E. 512 (1894); Warner's Estate, 30 Pa. D. \& C. 599 (1937) ; Weliman v. Cleveland Trust Co., 107 Ohio St. 267, 140 N. E. 104 (1923). See Note (1938) 117 A. L. R. 121, 124.

168. Sections 812 (d), 861 (a) (3) ; see Harrison v. Northern Trust Co., 317 U. S. 476 (1943) ; Elroy N. Clark, 1 T. C. 663 (1943). 
lems which require legislative response after a thorough reexamination of apportionment in all its ramifications. ${ }^{169}$ The rates have reached a level where mere tinkering here and there is inadequate. ${ }^{170}$

\section{Transferee Liability and Estate Tax Lien}

Another amendment provides that if the estate tax is not paid when due the "person in possession of the property by reason of the exercise. nonexercise, or release of a power of appointment" shall be personally liable for the tax "to the extent of the value, at the time of the decedent's death, of such property." A similar personal liability is imposed against all recipients of property includible in the gross estate. ${ }^{171}$ This amendment relates solely to the Government's right of collection, and does not affect the ultimate distribution of the tax burden among the various beneficiaries of the decedent's taxable assets. ${ }^{172}$ The 1942 Act also provides that all persons personally liable for tax under section 827 (b) are included within the term "transferee" for purposes of transferee proceedings. ${ }^{173}$ The appointive assets, like all property included in the gross estate, are subject to the ten-year estate tax lien. ${ }^{174}$

169. Compare the problems arising out of insurance payable in installments. Sce 1 PAur, op. cit. sutpra note 7 , at 787 .

170. The Treasury has proposed a federal apportionment statute. See statement of Mr. Paul, supra note 1, at 94. There is no reason for confining the federal statute to life insurance and powers of appointment. For a very early suggestion uf federal appurtionment, see Hearings before Committe on II'ays and Means acih Reference to the New Rezenue Bill, 65th Cong., 2d Sess. (1918) 1066.

171. Section \$27(b) of the Code, as amended by Pub. L. No. 753, \$411. Prior to this amendment personal liability was expressly imposed only against recipients of ta:sable inter vivos transfers and insurance beneficiaries. The committee reports, explaining the broadening of the section, state: ". . . all the assets referred to in section 811 [defining the gross estate] are treated equally for purposes of inclusion in the gross estate and the holders or recipients of all such assets are accordingly placed on the same plane of parsonal liability for the tax." H. R. Rep. No. 2333, 77th Cong., 2d Sess. (1942) 168; SE:. REP. No. 1631, 77th Cong., 2d Sess. (1942) 241. There is scope for further improvement. Compare the results in John Hancock Mutual Life Insurance Co. v. Helvering, 128 F. (2d) 745 (App. D. C. 1942) ; Equitable Life Assurance Sucicty, 46 B. T. A. 58\% (1942).

172. Section 827 (b) seems to be defective in various contexts. For example, suppare $A$ is the life tenant of trust property and $B$ is the donee of a power over the remainder. If $B$ predeceases $A, B$ 's will exercising the power, there is apparently no one in possession of the property by reason of the exercise of the power. The trustee's passession derives from the donor.

173. Section 900 (e), as amended by Pub. L. No. 753, 8411. See 1 Paut, op. cit. supra note 7 , at $\$ 13.50$.

174. Section $827(a)$. See, generally, Detroit Bank v. United States, 317 U. S. $33 y$ (1943). 


\section{The Gift Tax}

Any substantive amendment of the estate tax law involves a legislative consideration of the gift tax. ${ }^{175}$ Otherwise the estate tax changes might be conveniently avoided by inter vivos dispositions without any offsetting $\operatorname{tax}$ cost. The gift tax statute has therefore been expanded by an amendment ${ }^{176}$ which "is coextensive with the estate tax amendment." ${ }^{177}$ In short, the inter vivos release or exercise of a power of appointment constitutes a taxable gift. ${ }^{178}$ Furthermore, all powers to appoint are regarded as powers taxable under the gift tax, with the exception of the two types of powers which are exempt from estate tax. ${ }^{179}$

The amendment obviates the need of resolving a troublesome question. Prior to the amendment the gift tax, unlike the estate tax, was completely silent on the subject of powers of appointment. It was therefore thought that the release or exercise of a power during lifetime was not subject to gift tax, ${ }^{180}$ for it would seem strange to attribute to Congress the intention of taxing the inter vivos release of a general power where Congress had failed to impose estate tax on unexercised general powers relinquished through death, ${ }^{181}$ and while Congress had expressly imposed an estate tax upon an exercise it had failed to be so specific when levying a gift tax. On the other hand, it might be held that there is no need to visit all the sins of omission of the estate tax upon the gift tax. ${ }^{182}$ The language of the gift tax is extremely broad, and the committee reports emphasize the desire to reach all transactions whereby "property or a property right is donatively passed to or conferred upon another, regardless of the means or the device employed in its accomplishment." $183 \mathrm{~A}$

175. INT. Rev. CoDE, c. 4 (1939). The gift tax is also a junior partner of the income tax, see Smith v. Shaughnessy, 318 U. S. 176, 179, n. 1 (1943), and, as a result, complications ensue. See PAUL, op. cit. supra note $7, \S 7.02$ and v. 17 .

176. Pub. L. No. $753, \S 452$, adding a new subsection (c) to section 1000. In similar fashion Pub. L. No. 753, §453, inserts a gift tax amendment to supplement Pub. L. No. $753, \S 402$, which drastically revises the estate tax liability incurred by community property. See Comment (1942) 31 Calif. L. Rev. 60.

177. See H. R. Rep. No. 2333, 77th Cong., 2d Sess. (1942) 169; Sen. Rep. No. 1631, 77th Cong., 2d Sess. (1942) 242.

178. The statutory language is: "An exercise or release of a power of appointment shall be deemed a transfer of property by the individual possessing such power." See also U. S. Treas. Reg. 79, Art. 2(b).

179. There is also the proviso intended to prevent a succession of tax exempt powers.

180. Compare Griswold, supra note 50 at 953 ; Alexander, supra note 123, at 745.

181. See Edith Evelyn Clark, 47 B. T. A. 865, 866 (1942); cf. Commissioner v. Solomon, 124 F. (2d) 86 (C. C. A. 3d, 1941), which avoids the issue by holding that a power excluding the donee from its benefits is nongeneral. But cf. Eisenstein, supra note 1 , at $315,317$.

182. Compare 2 PaUl, op. cit. supra note 7, at 1168.

183. H. R. Rep. No. 708, 72d Cong., 1st Sess. (1932) 28 (1939-1 Cuns. Bull., Pt. 2, pp. 476-77) ; Sen. Rep. No. 665, 72d Cong., 1st Sess. (1932) 27 (1939-1 Cum. Buli., Pt. 
person who may appoint property to himself, but, in lieu of such appointment, releases the property to designated remaindermen, is in effect transferring his own property. ${ }^{184} \mathrm{He}$ has simply omitted an intermediate step. In addition, the inter vivos exercise of a general power might be regarded as a taxable gift in accordance with the sensible principle that "the concept of a transfer, so painfully developed in respect of taxes on estates, was not flung aside and scouted" in imposing tax "upon transfers during life." 185 Congress definitely intended to exact a price for inter vivos dispositions which avoided the estate tax net. ${ }^{180}$

The Senate report disclosed legislative awareness of the prublem of inter vivos exercise or release, stating that the amendments "should not be construed as a limitation upon the application of the existing gift tax law with respect to the exercise or release of a power of appointment." ${ }^{167}$ Questions of interpretation arising under the old statute would therefore be left entirely to the courts, without any legislative comment of a declaratory character. The Senate, however, approved a floor amendment, which was ultimately adopted in the 1942 Act, relieving from gift tax all releases of powers of appointment prior to January 1,1943. Subsequent amendments have extended the period for tax-free releases to June 30 , 1943 , and more recently to February $29,1944 .{ }^{185}$ The apparent purpose of these changes was to make certain that donees of existing powers who were releasing them in order to avoid the basic estate tax amendments would not be subjected to gift tax under the statute as it stood prior to amendment. ${ }^{189}$ The amendment, of course. goes further since it absolves from gift tax all releases prior to March 1, 19+4, regardless of motiva-

2, p. 524). See Smith v. Shaughnessy, 318 U. S. 176,180 (1943) ; Commissioner. v. Marshall, 125 F. (2d) 943,945 (C. C. A. 2d, 1942).

184. Prior to such release he is apparently liable for income tax on the Clifford principle. Richardson v. Commissioner, 121 F. (2d) 1 (C. C. A. 2d, 1941), cert. desicd, 314 U. S. 684 (1941); if. Andrew Jergens, 2 C. C. H. 1942 B. T. A. Serv. $\prod_{1} 12,823-Y^{7}$ (B. T. A. mem.).

185. Burnet v. Guggenheim, $2 S S$ U. S. $280,2 S 7$ (1933). This view is not derived from any interpretation of Estate of Sanford v. Commissioner, 308 U. S. 39 (1939), which would render the estate tax and the gift tax mutually exclusive in incidence, or prastically so. See Smith v. Shaughnessy, 31S U. S. 176 (1943) and Robinette v. Helvering, 318 U. S. 184 (1943), as to the evil days which have come upon this interpretation. Cf. Commissioner v. Solomon, 124 F. (2d) 86,88 (C. C. A. 3d, 1941).

186. See Estate of Sanford v. Commissioner, 308 U. S. 39, 44 (1939); 2 PAUL, op. cit. supra note $7, \S 15.04$.

187. Sen. Rep. No. 1631, 77th Cong., 2d Sess. (1942) 243.

188. H. J. Res. 365, 77th Cong., 2d Sess. (1942); Pub. L. No. 68, 78th Cong., 1st Sess. (1943) $\$ 10$.

189. See SS CoNG. REC. 8305-06 (1942). The floor amendment, introduced and explained by Senator Taft, was agreed to in conference, subject to technical changes in language. CoNF. Rep. No. 2586, 77th Cong., 2d Sess. (1942) 71 (Amendment No. 418).

190. See U. S. Treas. Reg. 79, Art. 2(b). Moreover, the statutory language is bread enough to free from gift tax the release of powers created aiter Oetober 21,1942 , the 
tion. ${ }^{190}$ However, nothing is said concerning the exercise of a power, and general powers exercised prior to such date should, it seems, be held taxable under the prior provisions of the gift tax. ${ }^{101}$

The statute provides that a release or exercise of a power of appointment is a taxable gift even though the power is exercisable in conjunction with another person and regardless of whether the latter has a substantial adverse interest. There is a deviation here from the usual pattern of gift tax liability. A person who creates a trust, reserving a power to revoke with the consent of another person, effects a taxable gift if the other person has a substantial adverse interest. ${ }^{102}$ The same transfer" attracts an estate tax, ${ }^{193}$ subject to the allowance of a credit for gift tax paid. ${ }^{194}$ However, the deviation is warranted. In the case of powers of appointment a use of the "substantial adverse interest" concept for gift tax purposes would permit the total avoidance of both estate and gift tax by the holder of the power through an inter vivos exercise or release. It is no longer a question merely of choosing the appropriate occasion for imposing tax as in the case of the settlor. ${ }^{105}$

date of enactment of the 1942 Act. Undoubtedly there was no real intention of producing this uncalled for result, as indicated by the more circumscribed langunge of the estate tax amendment. See p. 544 infra.

191. Compare discussion at p. 535 supra. This is the position taken in U. S. Treas. Reg. 79, Art. 2(b).

192. Commissioner v. Prouty, 115 F. (2d) 331 (C. C. A. 1st, 1940); sce Higgints v. Commissioner, 129 F. (2d) 237,241 (C. C. A. 1st, 1942), cert. denicd, 317 U. S. 658 (1942). Cf. George Washington, Sr., C. C. H. 1943 T. C. Serv. $\| 13,021$ (T. Ct. mem.). But cf. First National Bank of Birmingham v. United States, 25 F. Supp. 816 (N. D. Ala. 1939). See 2 Paul, op. cit. supra note 7, \$17.09.

193. Helvering v. City Bank Farmers Trust Co., 296 U. S. 85 (1935).

194. Sections 813 (a) (1) and (2), 936. The settlor is freed from income tax. Sce PAUL, op. cit. supra note 87, at 213; Ray, supra note 23 , at 1324 . Here we mect one of the sore spots of tax incidence which emphasizes the need for some correlation of the income, estate and gift taxes. See Commissioner v. Beck's Estate, 129 F. (2d) 243, 246 (C. C. A. 2d, 1942) ; Higgins v. Commissioner, 129 F. (2d) 237,239 (C. C. A. 1st, 1942), cert. denied, 317 U. S. 658 (1942); Commissioner v. Prouty, 115 F. (2d) 331, 337 (C. C. A. 1st, 1940); Magill, The Impact of Federal Taxes (1934) 31; 1 PaUL, op. cit. supra note 7, at 88, 285, c. 17; Greenfield, Correlation of Federal lncome, Estate and Gift Taxes (1942) 16 TeMple L. Q. 194; Griswold, supra note 62; Merry, Federal Estate and Gift Tax: Concept of a Transfer (1940) 38 Mrcir. L. Rev. 1032; Wales, Indian Gifts (1939) 34 ILL. L. REv. 119; Warren, Corrclation of Gift and Ëstatc Taxes (1941) 55 Harv. L. Rev. 1; Comment (1940) 40 CoL. L. Rev. 467.

195. There is no tax if the trustee is a corporation, since the gift tax statute embraces only transfers by individuals. See 2 PAUL, op. cit. supra note $7, \S 15.05$.

The gift tax, like the estate tax, now extends to a trustee's power to appoint property unless the power falls within either of the exempt categories. Future grants of authority must be carefully drawn and carefully accepted. It is advisable to note that a resignation may incur a gift tax if the substantive result is a release of the power. Here again complications intrude where the power is held by more than one trustee, emphasizing the need for clear limitation of trustees' authority. Also, as in the case of the 
The gift tax section raises the inevitable question of correlation with the estate $\operatorname{tax} .{ }^{196}$ On the whole, the relationship between the two taxes with respect to powers of appointment is fairly clear. If the donee exercises or releases the power during his lifetime, there is no estate tax liability unless, for example, the release or exercise is in contemplation of death or the donee retains a life estate in the appointive property. ${ }^{107}$ Furthermore, if the power is exercisable only by will, the power is taxable both as a gift and a death transfer only if the power is released, since an inter vivos exercise is forbidden.

There is one aspect of correlation, however, which may occasion some difficulty in the future. A donee of a general testamentary power may release it so that he is no longer able to appoint the property to persons other than his spouse and children. ${ }^{198}$ At his death, therefore, assuming that such a release is valid under local law, ${ }^{199}$ he would have a tax-exempt power. What are the tax consequences of such a partial release? The regulations, from the taxpayer's standpoint, are disconcertingly specific. They provide that if a taxable power is released or exercised in such fashion that it becomes a tax-exempt power, such release or exercise "does not preclude" the inclusion of the property in the donee's gross estate. It is then stated, by way of example, that if a donee of a general power reduces it to an exempt power, the appointive property is taxable under section $811(\mathrm{f})(1)(\mathrm{B})$ or (C). ${ }^{200}$ These provisions tax an exercise or release made in contemplation of death, and an exercise or release intended to take effect in possession or enjoyment at death or reserving to the de-

estate tax, a power to invade principal for one's own henefit is a tasable power of appointment. However, gift tax liability attaches only if the holder of the fower releases it. If he exercises the power there is no gift since he simply becomes outright owner of the property and from a tax point of view he is already the owner.

The release of a power to invade, which is not presently exercisable, is analugutus to a transfer by gift of a contingent interest which never ripens. Such transfer is subject to gift tax, determined by the value of the contingent interest at the date of transfer, and the subsequent disappearance of the interest and consequent collapse of the gift are irrelevant. Goodwin v. MicGowan, 47 F. Supp. 798 (WW. D. N. Y. 1942). The release of a contingent power should be similariy taxable. In valuing the transfer one should make due allowance for the contingency, but Robinette v. Helvering, 318 U. S. 184 (1943), seems to indicate that if the contingency is beyond the actuarial act no allowance is in order.

196. See note 194 supra.

197. See p. 501 supra. Compare Higgins v. Commissioner, 129 F. (2d) 237, 241 (C. C. A. 1st, 1942), cert. denied. 317 U. S. 658 (1942); Commissioner v. Marshall, 125 F. (2d) 943,948 (C. C. A. 2d, 1942); Herzog v. Cummissioner, 116 F. (2d) 591. 595-96 (C. C. A. 2d, 1941) ; 2 PAvi, op. cit. supra nute 7, $\$ 17.12$.

198. One purpose of such a release, apart from tax considerations, might be the desire to avoid the principle that the donee's creditors may reach assets appointed under a general power.

199. This question is considered at p. $\mathbf{5 5 0}$ infra.

200. U. S. Treas. Reg. $105, \S 81.24$ (b) (3). 
cedent the income from the property or the right "to designate the persons who shall possess or enjoy the property or the income therefrom." This is not all. On the gift tax side it is provided that the reduction in scope of a taxable power to a tax-exempt power is also a release subject to gift tax. ${ }^{201}$

Those who have drunk deeply-or too deeply-from Estate of Sanford *. Commissioner ${ }^{202}$ will obviously be horrified. ${ }^{203}$ The same appointive property is taxed both under the gift tax and the estate tax despite the fact that the Supreme Court in the Sanford case frowned at such "double taxition." ${ }^{204}$ But all illusions must come to an end sometime. The Supreme Court has recently held in Smith $\%$. Shaughnessy ${ }^{205}$ that there is no principle of mutual exclusiveness. We are now informed that "the gift tax amounts in some instances to a security, a form of clown-payment on the estate tax which secures the eventual payment of the latter; it is in no sense double taxation;" and "Congress has provided as its plan for integrating the estate and gift taxes this system of secured payment on gifts which will later be subject to the estate tax." 206 A good deal of broad langunge in the Sanford case ${ }^{207}$ is conveniently forgotten.

But the Sanford case may still be significant in another respect. As interpreted in Smith $v$. Shaughnessy it represents the principle that a transfer in trust is not a gift as long as the grantor retains the power "to

201. U. S. Treas. Reg. 79, Art. 2(b). These provisions apply only to releases after February 29, 1944, in view of the legislative grace period allowed for tax-frce releases. See pp. 544-45 infra.

202. 308 U. S. 39 (1939). In this case the Supreme Court held that the settlor's surrender of a power to revest the trust corpus in himself did not constitute a taxable gift as long as he retained the power to alter the beneficial interests for persons other than himself. See also the companion case of Rasquin v. Humphreys, 308 U. S. 54 (1939); and Hesslein v. Hoey, 91 F. (2d) 954 (C. C. A. 2d, 1937), cort. denicd, 302 U. S. 756 (1937) ; cf. Burnet v. Guggenheim, 288 U. S. 280 (1933). The Caurt was deeply impressed with the fact that the retention of the latter power subjected the trust to estate tax, and refused to sanction a gift tax in addition. See Porter v. Commissioner, 288 U. S. 436 (1933) ; cf. Chickering v. Commissioner, 118 F. (2d) 254 (C. C. A. 1st, 1941), cert. denied, 314 U. S. 636 (1941); Guggenheim v. Helvering, 117 F. (2d) 469 (C. C. A. 2d, 1941), cert. denied, 314 U. S. 621 (1941) ; Commissioner v. Chase National Bank, 82 F. (2d) 157 (C. C. A. 2d, 1936), cert. denied, 299 U. S. 552 (1936). Sce 1 PAUL, op. cit. supra note $7, \S 7.09$.

203. See, e.g., Friedland, Irrevocable Trusts (1942) 20 TAxes 651; Nossaman, Tares on Gifts Subject to Contingencies (1942) 20 TAxes 650.

204. The Sanford decision has been criticized at length in Warren, supra note 194, at 12 .

205. 318 U. S. 176 (1943). See also Robinette v. Helvering, 318 U. S. 184 (1943); United States v. Frank, 133 F. (2d) 1009 (C. C. A. 7th, 1943); Commissioner v. Marshall, 125 F. (2d) 943 (C. C. A. 2d, 1942); Commissioner v. McLean, 127 F. (2d) 942 (C. C. A. 5th, 19+2).

206. 318 U. S. at 179.

207. 308 U. S. at $44-46$. 
modify the terms of the arrangement so as to make other disposition of the property." 20 s It is therefore arguable that a gift tax does not attach to a partial release since the donee still retains the right to designate the ultimate takers of the property. However, as Smith a'. Shaughnessy discloses, it is not too difficult to side-step the Sanford case. The Supreme Court, in the latter case, was concerned "with a question to which Congress has given no answer in the words of the statute," and the Court supplied an answer "in conformity to the course of judicial decision applicable to a unified scheme of taxation of gifts whether made inter vivos or at death." ${ }^{209}$ Here, howerer, the gift tax statute expylicitly provides that a release of a power of appointment is a taxable transfer and that a power of appointment is any power to appoint property other than two stated exceptions. It seems to follow, therefore, that if the donee leaves himself merely an exempt power, he has fully released his power of appointment to the complete satisfaction of the gift tax language. Regardless of any residue of control, the power of appointment no lunger exists. ${ }^{210}$ Nor is this conclusion unduly embarrassed by the argument, advanced by the Supreme Court in the Sanford case, ${ }^{21}$ that secondary liability for gift tax would be incurred by persons who might never receive the property. ${ }^{212}$ It has been held that a taxable gift may occur despite "the indefiniteness of the eventual recipient." 213

208. 318 U. S. at 181.

209. $308 \mathrm{U}$. S. at 48.

210. Compare Alexander, supra note 123, at 752 .

211. 308 U. S. at 46. But $c f$. Warren, supra note 194 , at 17 . The Court also reasoned that if a trust were considered a completed gift despite the donor's power to change beneficiaries, it might be plausibly maintained that a gift in trust for charities was deductible even though the donor could at a later date route the property to private beneficiaries. However, the gift to charity would fail here because of uncertainty. The completeness of a gift for purposes of taxability is not identical with completeness for purposes of the charitable deduction. For example, if a donor creatcd a trust, recerving a power solely in another to alter beneficial interests, the transfer would be a tasable gift. Higgins v. Commissioner, 129 F. (2d) 237 (C. C. A. Ist, 1442), cert. desicd, 317 U. S. 658 (1942) ; Hernstadt v. Hoey, 47 F. Supp. 874 (S. D. N. Y. 1942); Altert D. Lasker, 1 T. C. 208 (1942). See 2 PAuL, op. cit. supra note 7, $\$ 17.11$. Cf. Herzog v. Commissioner, 116 F. (2d) 591 (C. C. A. 2d, 1941). But the donor would not be entitled to a charitable deduction, even if a charity were namcd initial beneficiary, breause of the outstanding power of amendment. Martha F. Mason, t6 B. T. A. 6:2 (1942).

212. Section 1009 provides that if the gift tax "is not paid when due, the dunce of any gift shall be personally liable for such tax to the extent of the value of such gift." The period allowed the Commissioner to proceed against the donee exceeds by one year the period applicable to the donor. Evelyn N. Moore, 1 T. C. 14 (1942).

213. Robinette v. Helvering, 318 U. S. 183, 187 (1943), appruving U. S. Treas. Reg. 79, Art. 3 (1936 ed.). See also Aldus C. Higgins, 4 B. T. A. 1123, 1130 (1941), aff'd, 129 F. (2d) 237, 242 (C. C. A. 1st, 1942), cert. denicd, 317 U. S. 658 (1942) ; Commissioner v. Marshall, 125 F. (2d) 943,946 (C. C. A. 2d, 1942) ; Herzug v. Commissioner, 116 F. (2d) $591,594-95$ (C. C. A. 2d, 1941); dissenting opiniun of 
It is reasonable, however, to impose only the gift tax or the estate tax unless there is some additional factor which renders both taxes applicable. As indicated above, the partial release of a taxable power so that it is exercisable only for the benefit of the exempt class of relatives fits snugly into the language of the gift tax statute. The choice of the gift tax is also supportable by the policy underlying the statute. The donee of a taxable power is regarded as owner of the property, for although he may not enjoy all the fruits of ownership, he has sufficient nibbles at the fruits to justify such treatment. ${ }^{214}$ If he transforms his taxable power into an exempt power, he has surrendered "tax" ownership, and is left with a power which would have been immune from estate tax if granted to him originally. ${ }^{215}$ Other factors may produce, in addition, an estate tax, as, for example, the retention of a life estate in the appointive property. The donee's position in this case seems to be analogous to that of a grantor who has reserved a life estate and surrendered all control, once it is agreed that the discretion reposing in a donec of a "tax-exempt power is not" tax control.

The estate tax also has reasonable claims to recognition. It is expressly provided that a release of a power intended to take effect in possession or enjoyment at death is subject to estate tax. And upon the basis of Reinecke $v$. Northern Trust Company ${ }^{\mathbf{2 1 6}}$ it may be concluded that the release does not take effect until death strikes. It is also provided that a

Judge Augustus N. Hand in Hesslein v. Hoey, 91 F. (2d) 954,957 (C. C. A. 2d, 1937), cert. denied, 302 U. S. 756 (1942).

214. Compare Burnet v. Wells, 289 U. S. 670,678 (1933).

215. This view is not necessarily opposed by $\S 811(f)(1)(C)$ (ii), which subjects to estate tax a release of a power whereby the donee retains "the right, either alone or in conjunction with any person, to designate the persons who shall passess or enjoy the property or the income therefrom." The legislative background of this provision dates back to the Joint Resolution of March 3, 1931, 46 STAT. 1516, c. 454, when Congress provided for an estate tax upon "a transfer under which the transferor has retained for his life or any period not ending before his death (1) the possession or enjoyment of, or the income from, the property or (2) the right to designate the persons who shall possess or enjoy the property or the income therefrom . . ." This Resolution was intended to overrule May v. Heiner, 281 U. S. 238 (1930), and related decisions holding that a transfer reserving to the grantor a life estate was not subject to estate tax. Section 803 (a) of the 1932 Act amended the Resolution in various respects in order to "clarify" it and section 803 (b) added a similar provision with respect to powers of appointment. See H. R. Rep. No. 708, 72d Cong., 1st Sess. (1932) 47 (1939-1 Cur. Bull., Pt. 2, p. 491) ; Sen. Rep. No. 665, 72d Cong., 1st Sess. (1932) 50 (1939-1 Cur. Buti., Pt. 2, p. 532). The Resolution's reference to the decedent's reservation of a right to designate who shall possess or enjoy the property or its income was apparently intended to embrace a reservation analogous to a life estate, i.e., the right to designate the person who would enjoy or possess the property for the duration of the decedent's life. A reserved power to determine the eventual takers of property after death was already taxable under subsections (c) and (d) of the prior versions of section 811 of the Code.

216. 278 U. S. 339 (1929). 
release is taxable if the decedent retains the right "either alone or in conjunction with any person, to designate the persons who shall possess or enjoy the property or the income therefrom." "21i It therefore seems to follow that the donee of a taxable power can escape estate tax only by a total release, and that the gift tax does not come into play until such a release occurs. Furthermore, if a donee effected a partial release so that his power was rendered tax-exempt, and thereafter released his reduced power, ${ }^{218}$ both acts of release would have to he correlated in order to spell out a release of a power of appointment subject to sift tax. ${ }^{210}$

The Treasury's interpretation that both the gift and estates taxes are applicable may be examined in another light. If an owner of property creates a trust, retaining broad powers of revocation and amendment, and thereafter narrows his power so that he can merely reallocate portions of the property among his children, he is not liable for the gift $\operatorname{tax}^{229}$ and the trust property is included in his gross estate at death. ${ }^{221}$ On the other hand, if a donee of a general power of appointment narrows his appuintive authority in similar fashion he is subjected to the burden of both the estate and the gift tax. There does not seem to be any policy consideration in support of this difference in tax incidence, and policy is a furmidable factor where ambiguities are to be resolved. ${ }^{222}$

217. But see note 215 supra.

218. As to the releasability of special powers, sce note 231 infra.

219. Compare Estate of Sanford v. Commissioner, 30 U. S. 39 (1939). There in the additional consideration that if only a gift tax is imposed upon the reduction of a taxable power to an excepted power, holders of powers of appointment may occupy a better position than complete owners of property. The latter must transfer their pruferty entirely to escape estate tax, while the former could retain authrrity to determine the devolution without paying any estate tax.

220. See Doris Bond Sherman, 41 B. T. A. 898 (1940); cf. Commissioner v. Warner, 127 F. (2d) 913 (C. C. A. 9th, 1942) ; Leonard A. Yerkes, 47 B. T. A. 431 (1942).

221. Commissioner v. Chase National Bank, 82 F. (2d) 157 (C. C. A. 2d, 1936), ecrl. dessied, 299 U. S. 552 (1936); see 1 PAur, of. cit. supra note 7, at 318.

222. The gift tax amendments do not include any provision which revises the section allowing a deduction for contributions to charity. $\$ 1004$ (a) (2), (b). As indieated in the committee reports, H. R. Rep. No. 2333, 77th Cong., 2d Sess. (1942); SE::. Rer. No. 1631,77 th Cong., $2 d$ Sess. (1942) 242, such a provision is unnecessary since the releace or exercise of a power of appointment is now considered a transfer by giit. The expansion of the gift concept necessarily broadens the tax lien imposed on giits, extends personal liability in the case of appointive property, $\S 1009$, and places the recipients of ta:able property within the transferee category. $\$ 1025(\mathrm{f})$. The appointee or taker in default, as transferee, may be pursued by the Government after the statute of limitativins has run with respect to the holder of the power. Cf. Evelyn N. Mivire, 1 T. C. 14 (1942); Ralph Perkins, C. C. H. 1943 T. C. Serv. $\llbracket 13,037$ (T. Ct. mem.). See, further, Fletehiss Trust Co., 1 T. C. 798 (1943), in the event that the appointment is in trust. The amendments do not provide for apportionment of the gift tax burden. Since the giit tax is now imposed on powers not exercisable for the benefit of the holder of the puwer, it may be advisable to add a provision making the appointive property ultimately liable for the portion of tax attributable to the power. There is no yuestiun of interpretation 


\section{Effective Date of Amendments}

A statute which seriously restricts the pleasant pastures of avoidance raises a delicate question: How should one treat those who have already managed to get into the pastures? There is another, perhaps equally delicate, question: How is one to distinguish between those who have been motivated by avoidance and those who have not, assuming that the distinction should be made? The latter question is particularly relevant in connection with powers, since it is often impossible to effect a timcly release in order to escape the impact of a serious change in tax policy.

The bill, as passed by the House, provided that (1) the estate tax amendments were applicable only to estates of decedents dying after the date of enactment of the bill; (2) powers other than those exercisable in favor of the decedent, his estate, his creditors, or the creditors of his estate, ${ }^{223}$ were not subject to the amendments if (a) the power was released by the decedent before two years after the date of enactment, or if (b) the power was exercised on or before the date of enactment; and (3) the amendments did not apply to any power released on or before the date of enactment. ${ }^{224}$ The provision that all powers are immune from tax if released prior to the date of enactment may have been motivated by a desire to avoid any charges that the amendments violated due process because of retroactivity. ${ }^{225}$ The benefits, nevertheless, accrued to those holders of general powers who effected timely releases for the very purpose of avoiding tax under the amendments. ${ }^{226}$ While the new statute did not tax a release per se, the relinquishment of an otherwise taxable power after passage of the Act would naturally inspire the argument that the holder acted in contemplation of death because the purpose of the release was avoidance of estate tax. ${ }^{227}$ The gift tax amendments had similar provisions with respect to outstanding powers and previously released powers, ${ }^{228}$ but since the substantive changes were not effective

as to previously taxed property, since the deduction of the value of such property is not recognized under the gift tax.

223. See Eisenstein, supra note 1, at 310, 314.

224. See H. R. REP. No. 2333, 77th Cong., 2d Sess. (1942) 161. The report warned: "A power exercised by a decedent dying after the date of enactment of this section in a will executed prior to such date is considered to be exercised after such date." Sce also Sen. Rep. No. 1631, 77th Cong., 2d Sess. (1942) 234.

225. Compare Hassett v. Welch, 303 U. S. 303 (1938).

226. Compare Untermyer v. Anderson, 276 U. S. 440 (1928), holding that the gift tax statute, if applied to gifts made while the conference report on the statute was pending, was repugnant to due process. The decision would probably not be followed today.

227. Compare First Trust \& Deposit Co. v. Shaughnessy, 134 F. (2d) 940 (C. C. A. 2d, 1943) ; Farmers' Loan \& Trust Co. v. Bowers, 98 F. (2d) 794 (C. C. A. 2d, 1938), cert. denicd, 306 U. S. 648 (1939); U. S. Treas. Reg. 105, \$ 81.16. See 1 PauL, op. cit. supra note $7, \S \S 6.06,6.15$.

228. See H. R. 7378, 77th Cong., 2d Sess. (1942) §452(b). 
until January 1, 1943, holders of all powers had an additional period of time, after the passage of the bill, to execute a release. ${ }^{299}$

The Senate Finance Committee made two significant changes with respect to the estate tax. ${ }^{230}$ Powers not exercisable in favor of the donee, his estate or creditors were absolved from tax if the powers were not exercised after the date of enactment of the bill. This change made "allowance for the inability to release various nongeneral powers under applicable local law," ${ }^{231}$ and in this respect was a marked improvement of the House measure. ${ }^{232}$ The other change was apparently an attempt to assist those who were unable to avoid tax by a timely release because of a legal disability, as, for example, infancy or insanity. It was provided that the amendments are not applicable to powers exercisable in favor of the decedent, his estate or creditors, created on or before the date of enactment, if at that date the donee of such power is under a legal disability to release it, until six months after the disability ceases.33 For

229. Pub. L. No. 753, \$451.

230. The Committee also made technical changes in language.

231. CoNf. REp. No. 2586, 77th Cong., 2d Sess. (1942) 69 (Amendment No. 399). See also SEN. REP. No. 1631, 77th Cong., 2d Sess. (1942) 56. According to the Restatement, a special power is not releasable unless (a) the power is exercisable at the date of release and all the takers in default are persons to whom an effective appointment could then be made, or (b) the donor in creating the power manifests his intention that the power shall be releasable. 3 Restatesrent, Property (1940) $\$ \$ 334,335$. Cf. Gray, Release and Discharge of Pouers (1911) 24 HARv. L. Rev. 511; Comment (1910) 23 HARv. L. REv. 394. But compare the more liberal views expressed in Thorington v. Thorington, 82 Ala. 489, 1 So. 716 (1887); Baker v. Wilmert, 288 Ill. 434, 123 న. E. 627 (1919) ; Columbia Trust Co. v. Christopher, 133 Ky. 335, 117 S. W. 943 (1909); 1 Sinfes, Future Interests (1936) \$277 et seq.; Simes, Pouters in Trust and the Tcrmination of Powers by the Donee (1927) 37 YALE L. J. 63, 211; Nossaman, Relcase of Pouvers of Appointment. (1943) $56 \mathrm{HARv}$. L. Rev. 757, 762. See also the statutes enacted in Illinois, Iowa, Maryland, Massachusetts, New Jersey, New York, Pennsylvania and Rhode Island, cited in note 245 , infra.

232. In view of Helvering v. Grinnell, 294 U. S. 153 (1935), an appointment to taliers in default of shares identical with those designated in default of an appointment is an "exercise" The question of "passing" is entirely irrelevant. See Eisenstein, supra note 1, at 318. Cf. Commissioner v. Rogers, 135 F. (2d) 35 (C. C. A. 2d, 1943).

233. This provision, because of somewhat ambiguous phrasing, might create an inference that an exercise as well as a release before the termination of the sis-month period would escape tax. However, it seems clear that the intention was to put those unable to effect a timely release because of a legal disability in the same position as those who were able to move swiftly and avoid tax. Furthermore, it would be extremely incongruous to allow an additional period for the exercise of a general power, and provide a rigid rule that nongeneral powers, if exercised, are taxable, even if the holder of the power was under a legal disability when the bill was enacted. The regulations take the more sensible position that the provision only extends the time allowed to effect a tas-free release. U. S. Treas. Reg. 105, $\$ \$ 1.24$ (b) (3) (iii). See also Miclueas, Potiers of Appoiztment and the 1942 Rerenne Act (1943) 21 TAxes 198, 239. As a result, however, a donee of a taxable power who is mentally incompetent on the date of enactment but 
the purpose of this provision, a person in the armed forces of the United States is under a legal disability until the termination of the present war. ${ }^{234}$ Similar changes were made with respect to the gift tax. ${ }^{235}$

The applicability provisions, as approved by the Senate Finance Committee, did not remain unchanged. Senator Taft introduced a floor amendment, approved by the Senate, which made the estate tax amendments inapplicable to powers released prior to January 1, 1943..$^{230}$ The purpose of this change was to afford persons more time to relinquish their powers. It was felt that no one "except the very well informed persons who are able to maintain a large staff of expert lawyers" would be aware of the opportunity to release his power and escape tax. In addition it was feared that a release after the date of enactnent would be considered made in contemplation of death. ${ }^{237}$ The Senate also acceptecl another amendment offered by the same Senator which expressly made certain that inter vivos releases would not be taxed as gifts under the existing gift tax law. The House agreed to these floor amendments and the other Senate changes, subject to certain technical amendments. ${ }^{238}$

Efforts to aid donees of existing powers did not terminate with the final enactment of the 1942 Act on October 21, 1942. Congress subsequently

who previously executed his will while competent to do so would be reached by the new law.

234. Pub. L. No. 753, $\S 403$ (d) (2). See Sen. Rep. No. 1631, 77th Cong., 2d Sess. (1942) 234. The regulations, U. S. Treas. Reg. 105, $\$ 81.24$ (b) (3) (iii), require that the person in the armed forces be in active service on the date of enactment of the Act. The Senate report and regulations state that "legal disability" includes the disability of all unborn child.

Pub. L. No. 753, $\$ 507$, extending the time for performing certain acts, postponed because of war, is not broad enuogh to cover releases by donees merely because they are in the armed forces. This section may, however, be employed to grant an extension of time to persons not in the armed forces where they are outside the Americas. Sec generally, T. D. 5216, 1943 Inr. Rev. Bull., No. 2, at 53.

235. See Sen. Rep. No. 1631, 77th Cong., 2d Sess. (1942) 242.

236. 88 Cong. Rec. 8305-06 (1942).

237. Id. at 8306. See also Hearings before Committee on Finance on H. R. 737s, 77th Cong., 2d Sess. (1942) 2348.

238. Conf. Rep. No. 2586, 77th Cong., 2d Sess. (1942) 69 (Amendment No. 399). 71 (Amendment No. 418). Under a conference change, the estate tax amendments do not apply to unexercised powers where the decedent has died before January 1,1943 . This date was subsequently changed to July 1, 1943, by H. J. Res. 365, 77th Cong., 2d Sess. (1942), and to March 1, 1944, by Pub. L. No. 68, 78th Cong., 1st Sess. (1943) $\S 10$. The gift tax floor amendment referred to a "donated power to appoint." The word "donated," which is not used elsewhere, was dropped in conference. The report, however, emphasizes that the basic gift tax amendments "apply only to powers received by the individual from another person, and do not affect the present status of powers reserved to an individual by himself. See Estate of Sanford v. Comm. (308 U. S. 39 (1939))." There is obviously no intention to affect the law governing reserved powers, . and the committee statement is simply directed to any conftsion which may arise because the word "donated" was omitted in the section as finally enacted. 
extended by a joint resolution the period allowed for the tax-free release of a power exercisable in favor of the donee, his estate, or creditors to June $30,1943 .{ }^{239}$ This extension was motivated by a number of factors: (1) the inability of trustees to adjust their affairs within the period originally allowed; (2) the short period otherwise remaining "for the solution of many problems of law requiring further study by the holders of powers and their legal advisers"; (3) the probable failure of the regulations, because of their late appearance, to furnish any practical assistance to taxpayers. ${ }^{240}$ More recently Congress has granted an additional extension of time terminating on February 29, 1944..41

\section{ReLEasability UNDer Local LaW}

Congressional generosity toward holders of existing general powers is rooted in the implicit assumption that such powers are releasable in all jurisdictions. While Congress was beset with doubts where special powers were concerned, it apparently walked with assurance in the realm of general powers. ${ }^{242}$ Local property law, of course, has the final word on the releasability of powers ${ }^{243}$ - the same property law which has been treated so condescendingly in recent Supreme Court opinions. ${ }^{24}$ Tax law therefore resolves itself into a lowly question of property law and one must determine whether the Congressional assumption was correct. If, in a particular jurisdiction, general powers are not releasable, then the intended relief has been thwarted.

It is no exaggeration to state that there is practically no American law on the release of powers of appointment, if by law one means what courts have said in the past. ${ }^{245}$ Uncertainties, however, are considerably nar-

239. H. J. Res. 365, 77th Cong., 2d Sess. (1942). Donees under a legal disability on the date of enactment of the 1942 Act are given an additional six-month period aiter the disability ceases. Furthermore, if the donee dies prior to the expiration of such sismonth period and the power is unexercised, there is no tax. U. S. Treas. Reg. 105, $\$ 81.24$ (b) (3) (ii) ; U. S. Treas. Reg. 79, Art. 2(b) (3). Literally interpreted, Pub. L. No.753, $\$ 453$ (b) (2) and (c), as amended by the Resolution, would not prevent the imposition of a gift tax under the previous law if the donee under a disability released his power after July 1, 1943. However, the gift tax regulations provide that such a release is not taxable and therefore waive any claim under the old law.

240. See H. R. Rep. No. 2708, 77th Cong., 2d Sess. (1942); Ses. Rrs. No. 1832, 77th Cong., 2d Sess. (1942); 88 CoNG. Rec. 9720, 9812 (1942).

241. Pub. L. No. 68, 78th Cong., 1st Sess. (1943) \&10.

242. The regulations, however, are prepared against the possibility that local law may prohibit the release of a general power. U. S. Treas. Keg. 105, $\$ 81.24$ (b) (3) (iii); U. S. Treas. Reg. 79, Art. 2(b) (3).

243. Compare Helvering v. Stuart, 317 U. S. 154, 161 (1942).

244. See, e.g., Smith v. Shaughnessy, 318 U. S. 176, 180 (1943); Helvering v. Clifford, 309 U. S. 331,334 (1940); Helvering v. Hallods, 309 U. S. 105, 118 (1940); United States v. Jacobs, 306 U. S. 363,369 (1939).

245. See Nossaman, Release of Poüers of Appointment (1943) 56 Hnrv. L. Rev. 757. In general, there is hardly any American law of powers of appointment. But tax: 
rowed since the question of release is critical only with respect to general powers. ${ }^{246}$ And general powers are a problem only where they are exclusively testamentary. ${ }^{247} \mathrm{~A}$ bare handful of decisions has returned the verdict that general testamentary powers are releasable ${ }^{218}$ even though the donor evidently intended the donee to retain his discretion until "the moment of inevitable surrender." ${ }^{240}$ This result has been sharply criticized as a betrayal of the donor's trust and as sanctioning appointments by deed where the donor ordained that only a testamentary appointment would do. ${ }^{250}$ Even those who have accepted the rule that general testamentary

law is now functioning as a stimulant. Thus nine states have, as a result of the federal tax changes, enacted statutes governing the release of powers of appointment. Ill. Laws 1943, p. 59; Iowa Laws 1943, p. 319; Md. Laws 1943, c. 870; Mass. Laws 1943, c. 152 ; N. J. Laws 1943 , p. 51 ; N. Y. Laws 1943 , c. 476 ; N. C. Laws 1943 , p. 427; Pa. Laws 1943, p. 677 ; R. I. Laws 1943, p. 93.

246. See, in connection with special powers, note 231 supra.

247. General powers exercisable by deed or will are clearly releasable. 3 REstATEMENT, PROPERTY (1940) \$334.

248. Johnson v. Harris, 202 Ky. 193, 259 S. W. 35 (1924); Merrill v. Lynch, 173 Misc. 39, 13 N. Y. S. (2d) 514 (Sup. Ct. 1939) ; Lyon v. Alexander, 304 Pa. 288, 156 Atl. 84 (1931) ; Governor v. Bowen, 15 R. I. 549, 10 Atl. 589 (1887). See 3 RestutEMent, Property (1940) §334; 1 Sines, op. cit. supra note 231, §282; Alexander, supra note 123, at 749; Nossaman, supra note 245, at 761. But cf. Learned v. Tallmadge, 20 Barb. Ch. 443 (N. Y. 1856); Gray, supra note 231, at 530. It has been suggested that Lyon v. Alezander could have been decided on narrower grounds. Sec Comment (1935) 48 HARv. L. REv. 1202, 1245. The special considerations evoked by powers appendant, assuming that they still exist [but see 3 Restatement, Property (1940) \$325] are not considered here. See Note (1932) 76 A. L. R. 1430, 1437; Nossaman, supra note 245, at 760. Statutes in Iowa, Illinois, Maryland, Massachusetts, New Jersey, New York; Pennsylvania and Rhode Island sanction the release of general powers. See note 245 silpra.

249. Compare United States v. Wells, 283 U. S. 102, 117 (1931).

250. See Gray, supra note 231 , at 531 ; Note (1932) 76 A. L. R. 1430. The desire to protect the donor's intention that the appointment shall be testamentary has borne fruit in decisions refusing to enforce specifically a contract to appoint property. Wills $v$. Burns, $60 \mathrm{Md}$. 64 (1882); Farmers' Loan and Trust Co. v. Mortimer, 219 N. Y. 290, 114 N. E. 389 (1916), (1917) 30 Harv. L. Rev. 401; Beyfus v. Lawley [1903] A. C. 411. There is conflict as to whether the disappointed promisee is entitled to damages. Compare Northern Trust Co. v. Porter, 368 Ill. 256, 13 N. E. (2d) 487 (1938), 51 Hanv. L. Rev. 1451, with Re Parkin, [1892] 3 Ch. 510. See 3 Restatentent, Property (1940) $\$ 340$; Comment (1917) 17 CoL. L. REv. 235. The question is left open in the Mortimer case. However, an exception is made where the promise is to a taker in clefault, for in such case the promise to appoint not less than, or not to reduce the share in default below, a stated sum is effective as a release. In $r e$ Evered, [1910] 2 Ch. Div. 147; 3 Restratement, Property (1940) $\$ 336$, comment $b, \S 340$, comment $d$; cf. Coffin v. Cooper, 2 Drew. \& Sm. 365 (Ch. 1865); Palmer v. Locke, 15 Ch. D. 294 (1879). But cf. In re Cooke, [1922] I' Ch. 292; In re Bradshazv, [1902] 1 Ch. 436; see Thacker v. Key, L. R. 8 Eq. 408, 414 (1869). 'See further, (1933) 77 Soc. J. 295, and (1938) 82 Sol. J. 848, for a discussion of whether a release can be mutually revoked. If the donee covenants to appoint a stated portion of the property to one of the takers in default and fails to fulfill such promise by appointment or failure to appoint, the promisee is entitled to the amount promised him, and the others must receive at least an equal amount, assuming that they 
powers may be released are sometimes a bit apologetic for their position. ${ }^{251}$ But principle is not entirely on the side of non-releasability. A rule that the donee may release his power "will operate in the interests of freer alienability of property." $2 \times 2$ Moreover, the general testamentary power is almost equivalent to full ownership and the ability to release is a reasonable reflection of the donee's broad control. ${ }^{2.5}$ The Restatement accordingly declares that a general power is releasable even though the donor expressly provides that the power shall not be released. .34

On the whole, it is fair to conclude that general testamentary powers, in view of the historical support afforded by English precedent, ${ }^{255}$ will be held releasable. Even property law, ${ }^{250}$ as well as tax law, has its moments of practicality. If the release is valid, the appointees or takers in default enjoy their property in toto, as Congress clearly intended. If the release is invalid, the tax collector's reaper slices off a goodly portion of the appointive property. Faced with these alternatives, a court has little choice as to where its judgment shall fall.25i Even if one were particularly concerned with the donor's intention, the most reasonable conclusion would be that if he had the choice he would select the road to tax immunity. There is little to fear from the claim that the release is invalid since the donee intended to benefit himself indirectly by reducing his taxes.

all share equally in default of appointment. However, such a release should not be given effect beyond the specific sum promised to the taker in default, because the power still remains as to the balance. For example, the donce could appoint all the property to the promisee. See In re Evered, supra; 3 Rest.uresrext, Pronerty (1940) \$ 336, Illustration IV, and comment $b$. The decisions sustaining a release of a general testamentary power and those refusing to enforce contracts to appoint under such powers are essentially irreconcilable in rationale. Cf. (1910) 23 HARv. L. REv. 394, 395. But "a page of history is worth a volume of logic." New York Trust Co. v. Eisner, 256 U. S. 345, 349 (1921). See, however, 1IcLucas, supra note 233, at 242.

251. See 3 Restatenent, Property (1940) \$334, comment $a$.

252. Simes, stipra note 231 , at 214 .

253. "No one has any interest in a general power of appointment except the donce of the power." Lyon v. Alexander, $304 \mathrm{~Pa}$. 288, 291. 156 Atl. 84.85 (1931). The came decision emphasizes that the donor has relinquished "all dead hand dominion over the property:"

254. 3 Restatexient, Property (1940) \$334, comment $b$.

255. See Note (1932) 76 A. L. R. 1430, 1433. In England a statute provides: " $A$ person to whom any power, whether coupled with an interest ur not, is given may ly deed release, or contract not to exercise, the power." $15 \& 16 \mathrm{G}$ \&. V, c. $20, \$ 155$. At the present time all powers, except powers in trust, are releasable. In the absence of statute the English courts had concluded that all powers, except powers in trust and possibly powers merely collateral, were releasable. See Srars, ap. cit. supra nute 231, $\$ 279$ et seq.

256. See, e.g., Commissioner v. Fidelity \& Columbia Trust Co., 285 Ky. 1, 146 S. W. • (2d) 3 (1940).

25\%. Compare Griswold, Pourers of Appointment and the Nero Recentse Act (1943) 56 HaRv. L. Rev. 739, 740. A court might be obsessed by seriuus doubts in the case of spendthrift provisions fettering the corpus as well as the income. 
Even if such an intention were otherwise fatal, ${ }^{258}$ the truth of the matter is that the appointees or takers in default have also profited by the release.

In view of this dearth of authority, taxpayers should be greatly relieved by the Treasury's decision to give them the benefit of any doubt. The regulations state:

"It is presumed that all general powers are releasable, unless the local law on the subject is to the contrary; and it is presumed that the method employed to release the power is effective, tunless it is not in accordance with the local law on the subject (or, in the absence of such local law, is not in accordance with the local law relating to similar transactions)." ${ }^{250}$

In short, if local decisional or statutory law is silent, the release will be recognized. ${ }^{260}$ Furthermore, the presumption that a general power is releasable should ordinarily apply even if local decisions have refused to recognize the release of special powers. ${ }^{261}$ It is not clear how the Treasury would rule if 'contrary decisions lived together in the same jurisdiction. ${ }^{22}$ However, one must still be careful as to the form of release em-

258. But see Lyon v. Alexander, 304 Pa. 288, 156 Atl. 84 (1931). Compare In ri' Somes, [1896] 1 Ch. 250; In re Radcliffe, [1892] 1 Ch. 227, with $I n$ re Little, 40 Ch. D. 418 (1889) ; Cunynghame v. Thurlow, 1 Russ. \& M. 436 (Ch. 1832). See, further, Coffin v. Cooper, 2 Drew. \& Sm. 365, 376 (Ch. 1865); In re Evered, [1910] 2 Ch. D. 147, 157.

259. U. S. Treas. Reg. 105, $\$ 81.24$ (b) (3) (iii). See also U. S. Treas. Reg. 79, Art. 2 (b).

260. Compare Alexander, sttpra note 123, at 747 .

261. Compare Lyon v. Alexander, 304 Pa. 288, 156 Atl. 84 (1931), which stustains the release of a general testamentary power and indicates a contrary view if the power were special. A local court, in holding a special power not releasable, might indicate in a dictum that a general testamentary power is also nonreleasable. In that event it seems that the presumption erected by the regulations might not apply.

262. If the question of local law should arise in a federal court, there are additional complications. In Helvering v. Stuart, 317 U. S. 154 (1942), it was held that a circuit court of appeals' determination of local law would not be reversed unless the Supreme Court had "a definite conviction of error in the conclusion." Cf. Waialua Co. v. Christian, 305 U. S. 91 (1938) ; Matos v. Alonso Hermanos, 300 U. S. 429 (1937). While the Stllart decision may be a fine display of judicial modesty on the part of the Supreme Court, such modesty has no place in the determination of tax liability under a federal statute. Cf. Helvering v. Fitch, 309 U. S. 149 (1940); Helvering v. Leonard, 310 U. S. 80 (1940); Shulman, The Demise of Swift v. Tyson (1938) 47 Y ALE L. J. 1336, 1350. Nor is the Court always so modest. See, e.g., Pearce v. Commissioner, 315 U. S. 543 (1942); cf. Public Utilities Comm. v, United Fuel Gas Co., 317 U. S. 456 (1943), 56 Harv. L. REv. 825; Texarkana v. Arkansas Gas Co., 306 U. S. 188 (1939); Railroad Comm. v. Los Angeles Ry. Co., 280 U. S. 145 (1929). The Stuart decision gives the circuit courts, in many cases, the final word on local law as it affects tax incidence. The atthority of the circuit courts is apparently similar to that enjoyed under the rule of Eric $R . R$. v. Tompkins, 304 U. S. 64 (1938). See Palmer v. Hoffman, 318 U. S. 109 (1943); MacGregor v. State Mutual Life Assurance Co., 315 U. S. 280 (1942), relied upon by the Court in the Stuart decision. Under the rule of the Tomplins decision the federal 
ployed, and since a release is in effect a conveyance, the formal niceties of conveyancing in the governing jurisdiction would have to be respected by the donee. ${ }^{263}$

Powers to amend or revoke a trust which qualify as taxable powers of appointment raise a separate question which may be briefly noted. Generally, it seems, such powers are eliminated by amending the trust instrument. Technically such an amendment may be considered an exercise rather than a release and therefore ineffective to avoid the new rules of tax incidence. Such treatment, however, would he completely at odds with the legislative desire to assist donees of existing general powers, especially trustees. ${ }^{204}$ If the act of amendment simply eliminates the power to revolie or amend the trust, it deserves the respect accorded to releases. ${ }^{205}$

The Treasury's liberality in the case of releases is further evidenced by its treatment of so-called partial releases. If a donee of an existing general power relinquishes his authority, prior to March 1, 1944, to such an extent that he thereafter possesses a tax-exempt power, ${ }^{966}$ he is not subject to estate or gift tax, assuming that such a partial release is valid

courts are required to look to local decisions and statutes in arder tu ascertain the gusprning law. Ruhlin v. N. Y. Life Ins. Co., 304 U. S. 202 (1938). Several Supreme Court decisions indicate that the federal courts must conform to decisiuns of lower state culurts rather than draw independent conclusions from the legal materials available. Fidelity Trust Co. v. Field, 311 U. S. 169 (1940) ; Six Companies v. Highway District, 311 U. S. 180 (1940); West v. A. T. \& T. Co., 311 U. S. 223 (1940); Stoner v. New Jurl: Life Insurance Co., 311 U. S. 464 (1940) ; see Huron Corp. v. Linciln Co., 312 U. S. 183, 189, n. 7 (1941) ; cf. Wichita Royalty Co. v. City Bank, 306 U. S. 103 (1939). But a deciciun of a lower state court is not necessarily a conclusive datum of local law. Lochlart $v$ Garden City Bank \& Trust Co., 116 F. (2d) 658 (C. C. A. 2d, 1940). In those states where local statutes or decisions are lacking the federal court should be able to go outcide the jurisdiction involved and, in effect, decide the issue as if it were sitting as a state court. See Corbin, The Common Law of the United States (1938) 47 YaLE L. J. 1351; Corbin,

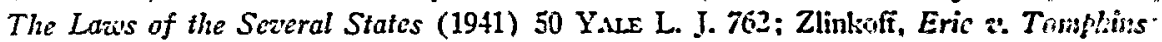
In Relation to the Law of Trade-Marks and Unfair Compatition (1942) +2 CoL. L. Rax. $955,966$.

263. For methods of release, see 3 Restatedrent, Properti (1940) \$336; Nosgaman, supra note 245 , at 766; MicLucas, supra note 233, at 242; Cumment (1930) 45 YaLE L. J. 516. Of particular interest in the present context are the instruments used in Merrill v. Lynch, 173 Misc. 39, 13 N. Y. S. (2d) 514 (Sup. Ct. 1939); and $/ \mathrm{sa}$ rc Brown's Settlement, [1939] 1 Ch. 944. See also the statutes of Illineis, Iowa, MIaryland, 1 Iassachusetts, New Jersey, New York, North Carolina and Pennsylvania cited in nute 245 supra, which set forth methods of release.

264. See p. 545 supra.

265. For example, if the trustees bestowed a tax-exempt power of appuintment upon another person, and thereafter surrendered their own powers of amendment it might bo held that they had exercised rather than released the power.

266. "Partial release" may also be used in the sense of a relinquishment of appuintive authority over a portion of the property rather than a narrowing of such discretion with respect to the entire property. See 3 Restatenewt, Propertr (1910) $\$ 336(4)$. See Atkinson v. Dowling, 33 S. C. 414,12 S. E. 93 (1890). 
under local law. ${ }^{267}$ This position is a wise translation of policy as reflected by the statutory scheme, since donees of outstanding general powers are enabled to obtain the benefits of tax immunity which Congress has explicitly sanctioned. ${ }^{268}$ There is no reason to discriminate between those who receive their powers today and those who received them yesterday. A partial release may often be very desirable apart from tax consequences. For example, a donee may have a general power with remainders in default of appointment to his children. If he releases his power in toto the children receive the property and the devolution is settled. But if he partially releases the power so that he may appoint only to his wife and children, he retains the power to provide for his wife as well as his children in the light of future exigencies.

The only real problem in regard to partial releases is whether they are recognized by local law. Here again American case law is uncomfortably silent. But law, like nature, abhors a vacuum, and one must assume that some governing principle exists impatiently awaiting discovery. In England it has been held that a partial release of a power is valid, and prohibits an appointment to those excluded by the release. ${ }^{200}$ Once it is assumed that a total release is permissible there is no reason to hold otherwise with respect to a partial release. ${ }^{270}$ Realistically speaking, if a release sins against the donor's intentions, the partial release is the lesser of the two sins. It is not entirely clear whether the presumption of validity expressed in the regulations includes partial releases, but the language employed is broad enough to cover such releases.

267. U. S. Treas. Reg. 105, $\$ 81.24$ (b) (3) ; U. S. Treas. Reg. 79, Art. 2. There are similar provisions with respect to persons under a legal disability on the date of chactment of the 1942 Act. See also C. C. H. 1940 Fed. Inh. Tax Serv. \6017. The rcgulations further provide that if a donee desires to bring his power within the "fiduciary" exception, he will not be deemed to have received a beneficial interest in property merely because he was the donee of a power created on or before the date of enactment of the 1942 Act. However, one should note that under section $811(\mathrm{f})(2)(B)$ of the Code a donee does not possess an exempt "fiduciary" power if he has acquired a beneficial interest in the property. The language of the provision seems to exclude the bencfit of the exemption even if the beneficial interest is surrendered prior to March 1, 1944.

268. But cf. Comment (1943) 43 CoL. L. Rev. 76. The donee of an existing special power which is taxable under the new provisions may be at a disadvantage if his power is not releasable. His immunity from tax depends upon his abstention from exercise, and he must therefore abide by the donor's arrangements in default of appointment or appoint the property and accept the tax consequences. The donee of a partially releasable general power may narrow it so that it qualifies for exemption and then mold the final arrangements to suit his own tastes.

269. In re Brown's Settlement, [1939] 1 Ch. 944, involving a special power. Sec In re Evered, [1910] 2 Ch. Div. 147, 157; Alexander, supra note 123, at 751.

270. See In re Brown's Settlement, [1939] 1 Ch. 944, 954. Legislation in Illinois, Iowa, Maryland, Massachusetts, New Jersey, New York and Pennsylvania expressly authorizes partial releases. The Rhode Island statute is not clear. See note 245 , supra. 


\section{Constitutionality}

It has been fashionable in the past to devote much attention to constitutional questions when considering tax legislation. especially in the estate tax field. Although section 403 and its gift tax adjunct, section 452 , malse striking changes in the tax incidence of powers, there is little to be said here. Certainly all doubts with respect to powers created henceforth are resolved by the IVhitney decision ${ }^{271}$ sustaining an estate tax upon a special power confined to the decedent-donee's children and the issue of deceased children. ${ }^{272}$ The case involved an exercised power, but its rationale is equally applicable to unexercised special powers. ${ }^{273}$ In the words of $\mathrm{Mr}$. Justice Frankfurter, "it is enough that one person acquires economic interests in property through the death of another person, even though such acquisition is in part the automatic consequence of death or related to the decedent merely because of his power to designate to whom and in what proportions among a restricted class the benefits shall fall." ${ }^{-74}$ Furthermore, unlike the statute intolved in the I'hitney case, the federal amendments expressly sanction tax-exempt powers within specified limitations. An apportionment provision is also included to aroid unfair distortion of estate tax incidence. Nor are any serious constitutional problems induced with respect to existing powers. The donee of a power exercisable in favor of himself, his estate or creditors is allowed a periud of readjustment to escape tax, and donees of other powers are unaffected if they refrain from exercise. ${ }^{275}$

\section{ConCLUSTON}

At the outset a significant query was quoted: "For what good reason should contemporary American taxpayers be allowed to skip a generation

271. Whitney v. State Tax Comm., 309 U. S. 530 (1940).

272. Compare Chanler v. Kelsey, 205 U. S. 466 (1907); Orr v. Gilman, 183 U. S. 278 (1902), involving succession tax.

273. Compare (1940) 40 CoL. L. Rev. 923, 927.

274. 309 U. S. at 538-39. See also id. at 539-41; cf. the principle of Porter v. Commissioner, 288 U. S. 436 (1933), which also applies where the power to alter bencficial shares is confined to a specified group. See 1 PAur, op. cit. stspra note 7, at 318-19. But cf. Leser v. Burnet, 46 F. (2d) 756 (C. C. A. 4th, 1931), to the effect that nothing passes under a special power, whereas under a general power sumething passes because the donee may exercise the power in favor of his creditors.

275. It is not implied that the absence of these legislative concessions would have constitutional repercussions. Cf. United States v. Jacobs, 306 U. S. 363 (1939); Saltonstall v. Saltonstall, 276 U. S. 260 (192S); see Chickering v. Commissioner, 118 F. (2d) 254, 260 (C. C. A. 1st, 1941), cert. denied, 314 U. S. 636 (1941). In the Whinsy ease the power in question was created in 1899 when New York had a legacy tax and the challenged estate tax statute was enacted in 1932. Cf. discussion in Schuyler, sisfra note 43 , at 791 et seq. There may be a constitutional tempest in a teapot if loeal law forbids the release of a general power. Cf. Alexander, stipra note 123, at 754, n. 61 . 
or two of estate and inheritances taxes by the use of a verbal form invented several centuries ago to enable an English gentleman to make a will?" 270 The 1942 Act fails to answer; it expressly sanctions the happy process of skipping. ${ }^{277}$ There has been much ado about powers, but now that the legislative smoke has lifted, we find that what was once accomplished by the general power may now be done by certain special powers. There will be grumbling, of course. One must be more cautious in doing things the tax-wise way and life has become more complicated for tax lawyers, if not more profitable. But the Government, from a revente standpoint, seems to be in about the same position it occupied when avoidance was simpler. At best it has cleared away the accumulated debris of cloctrine which like all irrelevancies may amuse and beguile but remain conspicuously reticent on the subject of revenue. There is still small comfort in applying a law whose yield little reflects the transfer of wealth from one generation to another. ${ }^{278}$

The effect of the new statute upon traditional modes of disposition is obviously drastic. One may safely predict that the general power will virtually disappear from trust settlements. The effects, moreover, will be felt beyond the intimate family circle. Creditors' rights, for example, will also be seriously affected, for established property doctrine has it that only general powers enable creditors to help themselves to appointive assets. But these effects hardly constitute respectable objections. A tax which lives by dominion and control of the decedent must penetrate beyond legalistic concepts of ownership. Those who transmit property must necessarily choose between the benefits of dominion and its disadvantages, including tax consequences. The 1918 statute subsidized powers of appointment, making it extremely unwise to transmit fee ownership. To that extent it invaded, as a practical matter, wonted prerogatives of ownership. The 1942 statute goes one step further in subjecting to tax general and related powers. At the same time certain special powers are subsidized, and owners of property are required to decide whether they will select one device or the other. The new statute narrows once more the tax-free scope of discretion, but this result is implicit in any effective estate tax measure.

The new statute places us upon the threshold of a basic truth which should have been faced many years ago. It is time to realize that trust settlements are an established form of ownership, and that the devolution of enjoyment from generation to generation, which it is the function of such settlements to safeguard, should be treated as a taxable event within

276. McDougal, supra note 43 , at 1114 .

277. Moreover, tax is entirely avoided if the power is entrusted exclusively to a trust company, which is not liable for estate and gift taxes.

278. Compare Alexander, supra note 123, at 754-55. 
the framework of the present statute or as a subject for a complementary levy. ${ }^{279}$ The skipping process does not inhere in powers; it derives from the tax favoritism based upon the life estate-remainder sequence. As long as that favoritism exists, the power of appointment has a reasonable claim to some immunity. Thus little is accomplished by venting legislative wrath upon powers, eradicating the glaring abuses, and stopping at that point. It is necessary to revise primitive death tax notions which build upon the necessity of control over property or "strings" upon it, ${ }^{2 S 9}$ the vestigial remainders of former ownership. We have been busy elaborating theories which would justify tax at death, and neglecting at the same time one of the most obvious reasons for imposing tax; the actual enjoyment of the fruits yielded by property and the termination of such enjoyment at death. The 1942 amendments will perform legion service if they transfer the attention lavished upon powers to the fundamental fallacy of the estate tax and the consequent skipping of one or more generations. ${ }^{281}$

279. Compare Mills, supra note 46; Griswold, supra note 47, at 959. See, in addition, 1 PAUL, sulpra note 7 , at 571 .

280. See Stone, J., dissenting in Helvering v. St. Louis Union Trust Company, 296 U. S. 39, 46 (1935). This dissent is now law. Helvering v. Hallock, 309 U. S. 106 (1940). 281. Only the unfortunate draftsmen would appreciate the difficulties of vriting a statute which destroys the skipping process. For example, one would probably have to make some adjustments with respect to the decedent's wife, who is of the same generation. Cf. MaGrL, op. cit. supra note 194, at 32; Griswold, supra note 257, at 741. The ta: status of the wife would also require a re-examination-long overdue-of the deduction far previously taxed property. 